\title{
Antifungal Properties of Essential Oils and Their Compounds for Application in Skin Fungal Infections: Conventional and Nonconventional Approaches
}

\author{
Aswir Abd Rashed 1,*(D), Devi-Nair Gunasegavan Rathi ${ }^{1}$ (D), Nor Atikah Husna Ahmad Nasir ${ }^{2}$ \\ and Ahmad Zuhairi Abd Rahman $3, *$ (D)
}

1 Nutrition, Metabolism and Cardiovascular Research Centre, Institute for Medical Research, National Institutes of Health, Ministry of Health Malaysia No.1, Jalan Setia Murni U13/52, Seksyen U13 Setia Alam, Shah Alam 40170, Malaysia; rathidevinair@moh.gov.my

2 Department of Biology, Faculty of Applied Science, Universiti Teknologi MARA (Perlis Branch), Arau 02600, Malaysia; atikah1388@uitm.edu.my

3 Cancer Research Centre, Institute for Medical Research, National Institutes of Health, Ministry of Health Malaysia, No.1, Jalan Setia Murni U13/52, Seksyen U13 Setia Alam, Shah Alam 40170, Malaysia

* Correspondence: aswir@moh.gov.my (A.A.R.); zuhairi.ar@moh.gov.my (A.Z.A.R.)

check for updates

Citation: Abd Rashed, A.;

Rathi, D.-N.G.; Ahmad Nasir, N.A.H.; Abd Rahman, A.Z. Antifungal Properties of Essential Oils and Their Compounds for Application in Skin Fungal Infections: Conventional and Nonconventional Approaches.

Molecules 2021, 26, 1093.

https://doi.org/10.3390/ molecules26041093

Academic Editors: Vivian Tullio,

Alessandra Guerrini and

Domenico Cautela

Received: 30 December 2020

Accepted: 31 January 2021

Published: 19 February 2021

Publisher's Note: MDPI stays neutral with regard to jurisdictional claims in published maps and institutional affiliations.

Copyright: (c) 2021 by the authors. Licensee MDPI, Basel, Switzerland. This article is an open access article distributed under the terms and conditions of the Creative Commons Attribution (CC BY) license (https:// creativecommons.org/licenses/by/ $4.0 /)$.

\begin{abstract}
Essential oils (EOs) are known to have varying degrees of antimicrobial properties that are mainly due to the presence of bioactive compounds. These include antiviral, nematicidal, antifungal, insecticidal and antioxidant properties. This review highlights the potential of EOs and their compounds for application as antifungal agents for the treatment of skin diseases via conventional and nonconventional approaches. A search was conducted using three databases (Scopus, Web of Science, Google Scholar), and all relevant articles from the period of 2010-2020 that are freely available in English were extracted. In our findings, EOs with a high percentage of monoterpenes showed strong ability as potential antifungal agents. Lavandula sp., Salvia sp., Thymus sp., Citrus sp., and Cymbopogon sp. were among the various species found to show excellent antifungal properties against various skin diseases. Some researchers developed advanced formulations such as gel, semi-solid, and ointment bases to further evaluate the effectiveness of EOs as antifungal agents. To date, most studies on the application of EOs as antifungal agents were performed using in vitro techniques, and only a limited number pursued in vivo and intervention-based research.
\end{abstract}

Keywords: skin fungus; essential oils; in vitro; in vivo; intervention

\section{Introduction}

Fungi are ubiquitous environmental microorganisms that may be categorized, according to their dimorphic morphology, as unicellular (yeast) or filamentous (molds). Almost one million mycotic species have been reported to exist in nature, with approximately 200 species identified as human pathogenic [1]. It has been found in recent years that fungal infections have contributed to increased mortality rates [2]. This phenomenon has been linked to certain age groups, especially premature neonates, infants and elderly people who are susceptible to underdeveloped or poor immune systems [3-5]. The most common species associated with deadly invasive and superficial infections are Candida sp., Aspergillus sp., and Cryptococcus sp. [6]. In addition, Fusarium sp. has been shown to cause opportunistic invasive fungal infections [5,7].

Aspergillus spp. is a filamentous and ubiquitous fungi with $A$. fumigatus as the major species associated with human disease, followed by A. flavus, A. niger and A. terreus [3,8,9]. In addition to the most common species, several other emerging species exist, including $A$. clavatus, A. nidulans, A. glaucus and A. ustus [6,9]. Fusarium spp. are other fungi that can cause human infections, and are the primary cause of fungal keratitis. This fungus is the 
second most common to infect severely immunocompromised patients and cause disseminated infection [10]. F. solani has been identified as the most frequent pathogen in fusarial keratitis incidence, while F. oxysporum leads to major incidences of onychomycosis [11-13]. Candida spp. are tiny, oval-shaped fungi with a thin cell wall that are capable of budding or fission. Among the identified species, five are the leading cause of invasive infections ( $C$. albicans, C. glabrata, C. parapsilosis, C. tropicals and, C. krusei) [14]. Invasive candidiasis often occurs as a form of healthcare-associated infection, where affected patients are typically receiving broad-spectrum antibiotic treatment, immunosuppressants, or suffering from cancer [15]. Candidiasis infections typically exist on the epithelial surfaces of the mouth, gastrointestinal tract, vagina and skin surfaces. C. albicans remains the most common cause of skin, nail and mucous membrane infections in healthy individuals, in whom it may also induce more severe infections of the vital organs [16,17].

In general, fungal diseases are differentiated into four groups: dermatophytosis, subcutaneous mycoses, systemic mycoses and other mycoses [4]. Dermatophytosis is caused by dermatophytes that attack and grow on dead animal keratin. Epidermophyton, Microsporum and Trichophyton are the three main genera related to dermatophytes. Dermatophytes are known as a species of fungi that typically infect and invade a living host's skin, hair and nails. Diseases caused by dermatophytes are typically classified according to the infection site, but are broadly referred to as tinea. Several forms of tinea are common such as Tinea capitis (scalp and hair), Tinea corporis (nonhairy skin), Tinea barbae (beard), Tinea cruris (groin), Tinea manuum (hand), Tinea pedis (feet) and Tinea unguium (nails, also called onchomyosis) [18]. According to current practice, five classes of conventional antifungal treatments are commonly applied. Figure 1 shows each antifungal agent and its mechanism of action.

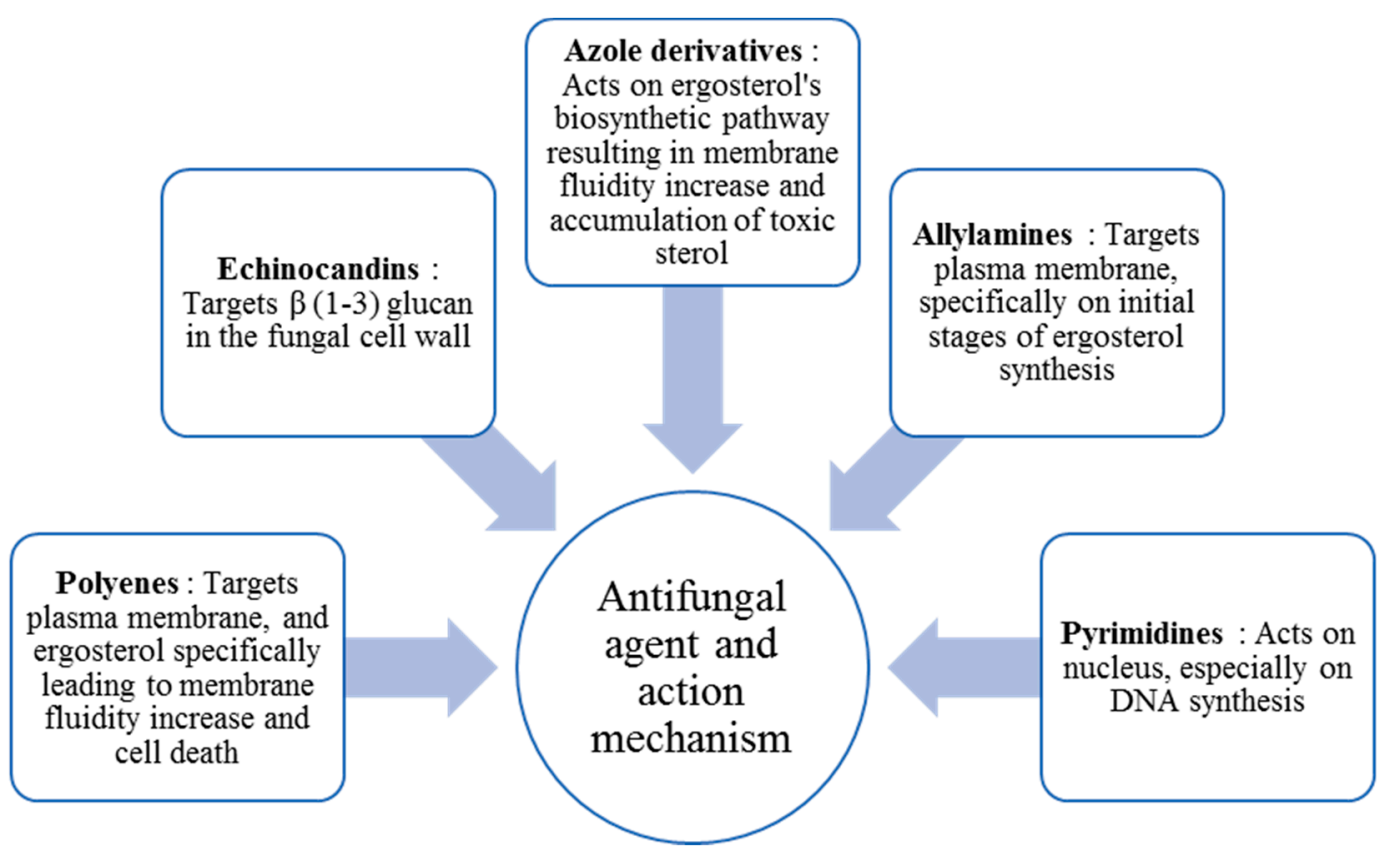

Figure 1. Conventional antifungal agents and their mechanisms of action (Adapted from [19]).

However, the treatment of fungal infections has encountered serious difficulties in the form of increased resistance due to the extensive use of antifungal agents. This situation has led to the insight that alternative, nonconventional approaches are required for effective antifungal treatment strategies. One of the possible directions proposed is the use of essential oils (EOs) as potential antifungal agents. EOs can be extracted from various plant parts and are volatile, aromatic, concentrated, hydrophobic oily liquids. Monoterpenes, sesquiterpenes and phenolic compounds are the key components of EOs. Phenolic compounds are chiefly responsible for the antimicrobial properties of Eos [20]. 
Numerous studies have proven the efficacy of EOs in antifungal treatments, although not all have addressed the underlying mechanisms of action [21]. The most widely used parameter in the antimicrobial assessment is minimum inhibitory concentration (MIC) and minimum fungicidal concentration (MFC), i.e., the lowest antifungal agent concentration required to inhibit fungal growth or to kill mycetes, respectively [2,22]. At present, thyme (Thymus sp.), tea tree (Melaleuca alternifolia), peppermint (Mentha piperita) or clove oil (Syzygium aromaticum) are the most widely tested EOs in terms of their antifungal activities [23-26]. Nevertheless, examination of the potential of EOs has extended to other types of oils [27]. Several examples of the use of EOs in the treatment of fungal diseases are described below.

Thyme EO (Thymus sp.) is recognized as a promising antifungal agent due to the presence of thymol and carvacrol at high concentrations [28]. A study conducted with one of the most common thyme EO, T. vulgaris, indicated strong antifungal activity against A. flavus at a concentration of $350 \mathrm{ppm}$ [29]. Rasooli and colleagues performed a comparative study of antifungal activity against $A$. niger using T. eriocalyx (Ronniger) Jalas, Rech.f. and T. $x$-porlock, showing superior activity of T. eriocalyx, with a MIC value of 125 ppm [30]. Another EO that has been widely explored is cinnamon oil (Cinnamomum sp.), with cinnamaldehyde as its major component. An investigation of the antifungal effect of C. zeylanicum exhibited a synergistic effect with Fluconazole against $A$. fumigatus [31-33]. Similarly, Eucalyptus globulus EO has been shown to possess potent antifungal activity; one study examined its effect on growth inhibition of A. flavus, A. niger, A. terreus and A. fumigatus [34]. S. aromaticum has also shown antifungal efficacy against different $A s-$ pergillus spp. (A. terreus, A. flavus and A. fumigatus) [29,35-37]. Additionally, Citrus sp., Mentha sp., and Cuminum sp. have been applied against Aspergillus spp. [36,38].

Fungal infections arising from Candida spp. are called candidiasis; the most commonly implicated species is C. albicans. Fluconazole and itraconazole are widely utilized for such infections, but these agents have caused azole resistance within Candida spp. [3,39,40]. The antifungal properties of EOs derived from Melaleuca sp., Origanum sp., Thymus sp., Mentha sp., Syzgium sp., Coriandrum sp., Cuminum sp. and several others against Candida spp. were noted [2]. Melaleuca sp. is the main genus to have been studied for its anticandida properties. In a study by Mondello and colleagues, it was observed that C. krusei and C. gabrata showed sensitivity towards M. alternifolia EO; additionally, all azole resistant $C$. albicans were killed within 30 and $60 \mathrm{~min}$ at $1 \%$ and $0.25 \%$ concentration, respectively [41]. Antifungal activity was also observed from T. pulegiosides EO, that inhibited C. albicans, C. glabrata, C. parapsilosis, C. krusei and C. guillermondii with a MIC value range of $0.32-0.64 \mu \mathrm{L} / \mathrm{mL}$ [28]. Peppermint EO is also highly capable as an antifungal agent. Studies have revealed its inhibition capacity against Candida spp., dermatophytes and Aspergillus spp. when tested within 40-7000, 800-3500 and 400-3500 $\mu \mathrm{g} / \mathrm{mL}$, respectively [42]. Lavandula angustifolia, or lavender EO has also exhibited excellent antifungal activity against Candida spp. [43,44]. Cumin EO effectiveness as an antifungal agent has also been proven with respect to C. albicans, resulting in MIC values of 3.90 and $11.71 \mu \mathrm{g} / \mathrm{mL}$ [45].

Despite the existence of numerous studies suggesting the suitability of EOs as an alternative treatment strategy for fungal infections, it should be noted that these properties are highly dependent on the composition of the EO itself. These compositions are prone to significant variability based upon the use of different plant parts or the harvesting season [27]. Terpenes and their metabolic derivatives constitute the major component of Eos; these include functional derivatives of alcohols (geraniol), ketones (menthone), esters (cedryl acetate) and phenols (thymol). In addition, nonterpene compounds derived from phenylpropane (eugenol) are present in smaller percentages [46]. Thus, the effects are subject to variations, due in part to combinations of ingredients. Curcuma longa $\mathrm{L}$. EO effects have been demonstrated against $A$. flavus, in addition to aflatoxin inhibition. An interesting observation with exposure to this $\mathrm{EO}$ was reported via scanning electron microscopy (SEM) analysis, that signified hyphae membranes and conidiophores damage in A. flavus [47]. Likewise, EO of Matricaria chamomilla L. flower was investigated against 
A. niger, revealing apparent destruction of cytoplasmic membranes and intracellular organelles, plasma membrane detachment from the cell wall and complete disorientation of the hyphal compartment [48]. In addition to modification of the ultrastructure, a number of studies have examined the underlying mechanisms behind the proapoptotic effects of EOs. An example of this is Ocimum sanctum L. EO, which induced major cytotoxicity in $C$. albicans, where complete ergosterol depletion, membrane disintegration, DNA fragmentation, increased outsourcing of membrane phosphatidylserine and cytochrome c oxidase activity were observed [49].

However, it has also been suggested that the cytotoxic effects of EOs are mediated by induction of reactive oxygen species (ROS) over synthesis and oxidative stress. A study performed with Anethum graveolens L. seed EO revealed apoptosis in a C. albicans strain via ATPase activity decrease, chromatin condensation, DNA fragmentation, phosphatidylserine exposure, cytochrome $\mathrm{c}$ release and metacaspase activation. This study highlighted the role of L-cysteine in the prevention of apoptosis, which is a sign of ROS action [50]. Aflatoxins, i.e., harmful fungal toxins, have also attracted much interest relative to the potential effects of EOs [21]. Several studies have suggested positive inhibition outcomes for aflatoxin with the application of EOs, such as Chenopodium ambrosioides L., that suppressed the synthesis of aflatoxin B1 by the aflatoxigenic strain of A. flavus [51]. Similar results were also observed with Zataria multiflora Boiss EO, which decreased the growth of aflatoxin in A. parasiticus, indicating a link with gene inhibition of the biosynthesis pathways for aflatoxin [52].

To date, our knowledge of the mechanisms of action of EOs is still minimal, with emphasis on concentration-dependence. In general, some apparent effects of EOs include loss of membrane integrity, reduction of ergosterol levels, inhibition of wall formation, inhibition of gene expression, and suppression of membrane ATPases and cytokine interactions $[53,54]$. As such, the effectiveness of the antifungal characteristics is believed to be associated with the properties of the respective major component, but standardization of assessment methodologies and measurement units is important for further comparisons and investigations $[27,55]$. It is widely anticipated that EOs will eventually replace traditional agents. Considerable research has been performed and reported on the possible utilization of these nonconventional approaches, mostly in the form of ointment, gels and others [56,57].

In this review, we focus on the potential utilization of EOs as an alternative treatment of fungal infections in humans, along with the classification of these approaches as conventional and nonconventional techniques.

\section{Results}

The search resulted in a total of 192 articles from the three search engines: Pubmed (42 articles), WoS (61 articles) and Scopus (89 articles). Nevertheless, 86 articles were identified with a refined search based on the availability of full text, peer reviewed articles and library collection access. Upon further assessment, only 41 full articles were found to be relevant and were included for final review (Figure 2). All of these articles were printed for further assessment. Upon conducting a thorough review, these 41 articles were classified into three categories: 32 articles were categorized as in vitro research, 7 as combination of in vitro and in vivo research and 2 articles as clinical interventions. Out of this, 5 in vitro studies and 3 combination studies were classified as descriptions of nonconventional technology (Table 1). Due to a lack of randomized controlled trials (RCT) in all but two articles, we could only include this topic in the form of a narrative review. 


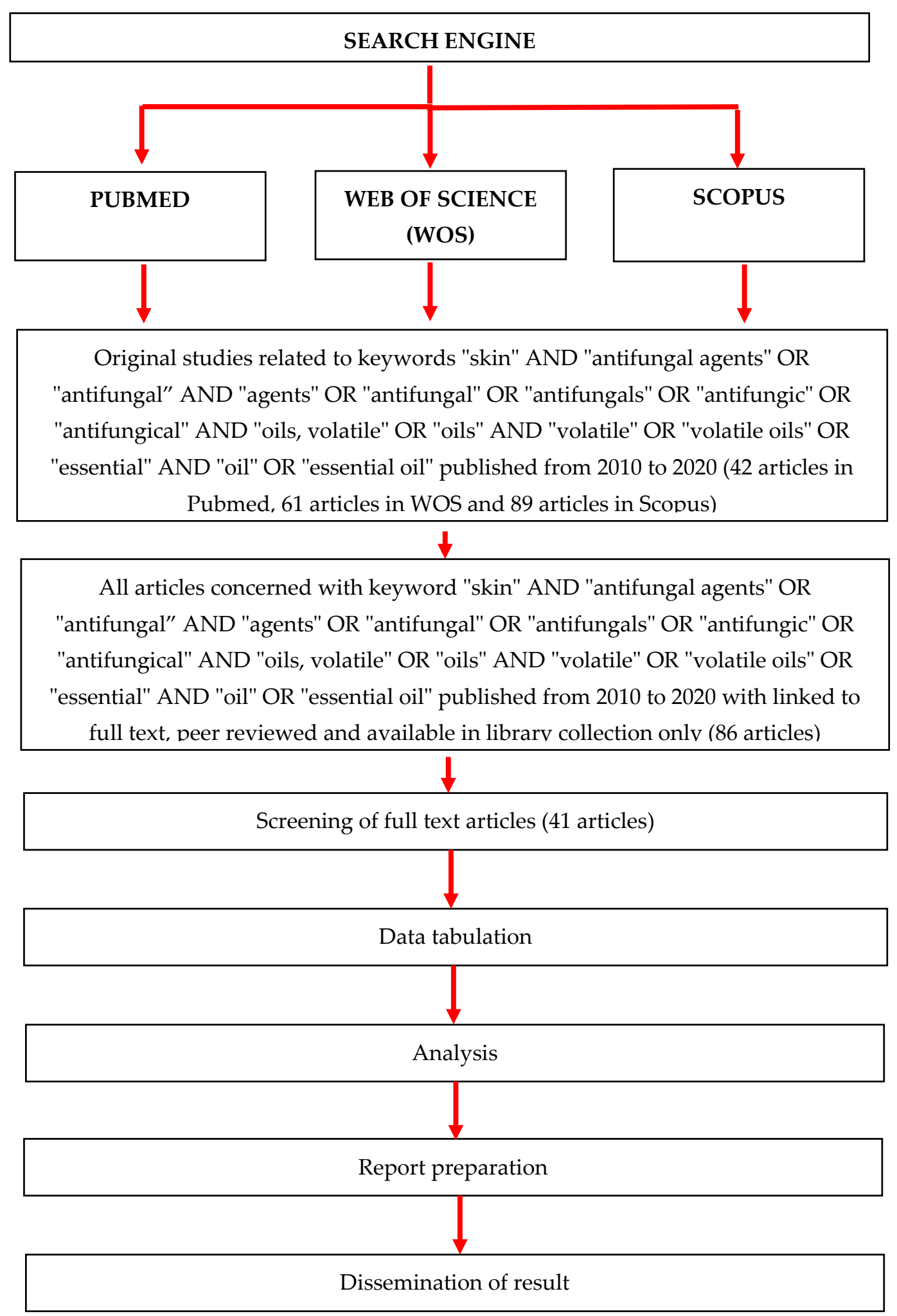

Figure 2. PRISMA flow diagram of the identification of literature for inclusion in this review. 
Table 1. Potential of EOs as antifungal agents in human skin disease.

\begin{tabular}{|c|c|c|c|c|c|c|c|}
\hline No. & Techniques & Reference & $\begin{array}{l}\text { Type of Skin Infections/ } \\
\text { Fungi Species }\end{array}$ & Essential Oils & Methods & Findings & Conclusion \\
\hline 1. & \multirow[t]{2}{*}{$\begin{array}{c}\text { In vitro-Conventional } \\
\text { technology }\end{array}$} & [58] & $\begin{array}{l}\text { Skin infections (C. albicans, } \\
\text { C. parapsilosis) }\end{array}$ & $\begin{array}{l}\text { Ten EOs: oregano, thyme, } \\
\text { clove, arborvitae, cassia, } \\
\text { lemongrass, melaleuca, } \\
\text { eucalyptus, lavender, and } \\
\text { clary sage }\end{array}$ & $\begin{array}{l}\text { EO compositions were } \\
\text { determined using gas } \\
\text { chromatography-mass } \\
\text { spectrometry (GC/MS). } \\
\text { The genotoxic effects on } \\
\text { healthy human } \\
\text { keratinocytes HaCaT of the } \\
\text { tested EOs were evaluated } \\
\text { using the comet assay }\end{array}$ & $\begin{array}{l}\text { - Oregano ( } 76.73 \% \text { carvacrol), } \\
\text { thyme }(53.26 \% \text { thymol), cassia } \\
\text { (77.83\% eugenol), lemongrass } \\
(45.72 \% \text { geranial) and } \\
\text { arborvitae (55.96\% methyl } \\
\text { thujate) showed very strong } \\
\text { antifungal activity against all } \\
\text { tested strains. } \\
\text { The results revealed that none } \\
\text { of the EO induced significant } \\
\text { DNA damage in vitro after } \\
24 \mathrm{~h} .\end{array}$ & $\begin{array}{l}\text { - These results showed that these ten } \\
\text { EOs may be effective in preventing the } \\
\text { growth of the drug-resistant } \\
\text { microorganisms which are responsible } \\
\text { for wound infections. This EO could be } \\
\text { used as a potential source of safe and } \\
\text { potent natural antimicrobial and } \\
\text { antioxidant agents in the } \\
\text { pharmaceutical and food industries. }\end{array}$ \\
\hline 2. & & [59] & $\begin{array}{l}\text { Dermatophytosis by } \\
\text { dermatophytes } \\
\text { (Trichophyton rubrum PTCC } \\
\text { (Persian Type Culture } \\
\text { Collection)5143, } T \text {. } \\
\text { mentagrophytes PTCC5054, } \\
\text { Microsporum canis } \\
\text { PTCC5069, M. gypseum } \\
\text { PTCC 5070, T. schoenleinii } \\
\text { PTCC5221, T. verrucosum } \\
\text { var. album PTCC 5056) }\end{array}$ & Artemisia sieberi oils & $\begin{array}{l}\text { - Analysis of five } A \text {. sieberi } \\
\text { oils (different harvesting } \\
\text { times and distinctive } \\
\text { collecting locations) by gas } \\
\text { chromatography-flame } \\
\text { ionization detector } \\
\text { (GC-FID) and GC-MS. } \\
\text { Antifungal activities of } A \text {. } \\
\text { sieberi oils were evaluated } \\
\text { against different } \\
\text { dermatophytes. } \\
\text { The oils were examined for } \\
\text { antidermatophyte activity } \\
\text { by the poisoned food } \\
\text { technique. } \\
\text { MIC and MFC were } \\
\text { determined by broth } \\
\text { microdilution assay. }\end{array}$ & $\begin{array}{l}\text { - The results showed that the } \\
\text { harvesting time and collecting } \\
\text { location affect the chemical } \\
\text { composition and oil yields. } \\
\text { The main components were } \\
\text { santolina alcohol, camphor, } \\
\alpha \text {-thujone and } \beta \text {-thujone. No } \\
\text { significant difference between } \\
\text { the desirable } \\
\text { antidermatophyte activities of } \\
\text { A. sieberi oils with different } \\
\text { chemical compositions. } \\
\text { M. gypseum, T. rubrum and } M \text {. } \\
\text { canis had more sensitivity } \\
\text { than others to } A \text {. sieberi oils. }\end{array}$ & $\begin{array}{l}\text { A. sieberi can be used as topical } \\
\text { antifungal agent for the treatment of } \\
\text { skin dermatophyte infections. }\end{array}$ \\
\hline 3. & $\begin{array}{c}\text { In vitro-Conventional } \\
\text { technology }\end{array}$ & {$[60]$} & $\begin{array}{l}\text { Various skin infection due } \\
\text { to pathogens (C. albicans } \\
\text { ATCC 10231, and } \\
\text { dermatophyte T. rubrum } \\
\text { SNB-TR) }\end{array}$ & $\begin{array}{l}\text { Coridothymus capitatus } \mathrm{L} ., \\
\text { Lavandula stoechas L., } \\
\text { Lavandula angustifolia Mill., } \\
\text { Mentha spicata L. subsp. } \\
\text { condensata, } \\
\text { Origanum syriacum L., } \\
\text { Rosmarinus officinalis, } \\
\text { Salvia rinticosa Miller., } \\
\text { Satureja cuneifolia Ten., } \\
\text { Satureja thymbra L., } \\
\text { Thymbra spicata L., and } \\
\text { Vitex agnus-castus L. }\end{array}$ & $\begin{array}{ll}\text { - } & \text { EOs composition analysis } \\
\text { by GC/MS. } \\
\text { Antimicrobial activity was } \\
\text { measured using a broth } \\
\text { microdilution method. }\end{array}$ & $\begin{array}{l}\text { EO with high amounts of } \\
\text { thymol and carvacrol } \\
\text { possessed the strongest } \\
\text { antimicrobial activity. } \\
\text { These two compounds } \\
\text { demonstrated interesting } \\
\text { antifungal efficacy against the } \\
\text { filamentous fungus T. rubrum. }\end{array}$ & $\begin{array}{l}\text { - This study highlights the in vitro } \\
\text { antimicrobial activity of some Lebanese } \\
\text { Lamiaceae EOs against human } \\
\text { pathogens. The antimicrobial potential } \\
\text { originates from their high content of } \\
\text { either thymol or carvacrol. The results } \\
\text { confirmed that some of the Lamiaceae } \\
\text { species used in Lebanon } \\
\text { ethnopharmacological practices as } \\
\text { antimicrobial agents possess } \\
\text { antibacterial and antifungal potential. }\end{array}$ \\
\hline
\end{tabular}


Table 1. Cont.

\begin{tabular}{|c|c|c|c|c|c|c|c|}
\hline No. & Techniques & Reference & $\begin{array}{l}\text { Type of Skin Infections/ } \\
\text { Fungi Species }\end{array}$ & Essential Oils & Methods & Findings & Conclusion \\
\hline 4. & & [61] & $\begin{array}{l}\text { Skin disease due to six } \\
\text { fungal strains (C. tropicalis, } \\
\text { C. albicans, , hhizomucor } \\
\text { miehei, C. glabrata, A. niger } \\
\text { and A. fumigates) }\end{array}$ & Myristica fragrans & $\begin{array}{l}\text { Volatile oil from the leaves } \\
\text { was isolated and } \\
\text { characterized by GC-MS. } \\
\text { Oil extracts were subjected } \\
\text { to antimicrobial assay } \\
\text { followed by the Kirby } \\
\text { Bauer method. }\end{array}$ & $\begin{array}{l}\text { - The most abundant } \\
\text { constituents identified were } \\
\beta \text {-pinene, } \alpha \text {-pinene and } \\
\alpha \text {-thujene. } \\
\text { The oil showed significant } \\
\text { inhibitory activity against the } \\
\text { fungus C. tropicalis }(1.3 \mathrm{~cm}), C \text {. } \\
\text { albicans }(0.8 \mathrm{~cm}), \text { R. miehei }(0.6 \\
\text { cm) and C. glabrata }(0.6 \mathrm{~cm}) . \\
\text { No inhibitory activity was } \\
\text { detected against } A . \text { niger and } \\
\text { A. fumigates. }\end{array}$ & $\begin{array}{l}\text { - The oil showed significant activity } \\
\text { against the tested fungi that suggest the } \\
\text { potential of Myristica fragrans } \mathrm{EO} \\
\text { against these diseases. }\end{array}$ \\
\hline 5. & & [62] & $\begin{array}{c}\text { Keratophilic fungi, a type } \\
\text { of dermatophytes causing } \\
\text { infection to hair, glabrous } \\
\text { skin and nails (A. flavus, T. } \\
\text { mentagrophytes, T. } \\
\text { tonsurans, T. verrucosum, } \\
\text { Epidermatophyton floccosum } \\
\text { and Microsporum nanum) }\end{array}$ & $\begin{array}{c}\text { Four different } \\
\text { commercially available Itra } \\
\text { (Volatile plant oils): Bella } \\
\text { (Lonicera x bella zabel), } \\
\text { Kewda (Pandanus } \\
\text { odoratissimus), Rajnigandha } \\
\text { (Polianthes tuberosa) and } \\
\text { Mogra (Jasminum sambac) }\end{array}$ & $\begin{array}{l}\text { The strains were identified } \\
\text { by a morphological study } \\
\text { of culture and microscopic } \\
\text { analyses of developed } \\
\text { colonies. } \\
\text { Antifungal activity of Itra } \\
\text { was tested against isolated } \\
\text { fungi using agar-well } \\
\text { diffusion method. }\end{array}$ & $\begin{array}{l}\text { - Better antifungal activity than } \\
\text { existing antifungal drugs like } \\
\text { terbinafine, itraconazole and } \\
\text { fluconazole (taken as control). } \\
\text { The maximum effect was } \\
\text { shown by Bella against } T \text {. } \\
\text { tosurans with inhibitory zone } \\
\text { of } 47 \mathrm{~mm} \text {. }\end{array}$ & $\begin{array}{l}\text { The paper concluded that Itra can be } \\
\text { used as an antifungal agent against } \\
\text { prevalent keratinophilic fungi. }\end{array}$ \\
\hline 6. & $\begin{array}{l}\text { In vitro-Conventional } \\
\text { technology }\end{array}$ & [63] & $\begin{array}{l}\text { Various skin diseases (C. } \\
\text { krusei H9, C. guillermondii } \\
\text { MAT23, C. albicans ATCC } \\
\text { 10231, C. tropicalis ATCC } \\
\text { 13803, C. parapsilosis ATCC } \\
\text { 90018, Cryptococcus } \\
\text { neoformans CECT 1078, T. } \\
\text { mentagrophytes FF7, } \\
\text { Microsporum canis FF, T. } \\
\text { rubrum CECT 2794, M. } \\
\text { gypseum CECT 2908, A. } \\
\text { niger F01, A. fumigatus F05, } \\
\text { A. fumigatus F07, A. } \\
\text { fumigatus F17, A. flavus F44, } \\
\text { A. niger ATCC 16404, A. } \\
\text { fumigatus ATCC } 46645\end{array}$ & $\begin{array}{l}\text { Four type oils obtained } \\
\text { from Thymus zygis subsp. } \\
\text { Sylvestris (collected at four } \\
\text { sites) }\end{array}$ & $\begin{array}{l}\text { Chemical profiling using } \\
\text { GC-FID and GC-MS. } \\
\text { A macrodilution broth } \\
\text { method was used to } \\
\text { determine the MIC and } \\
\text { minimum lethal } \\
\text { concentrations (MLC) for } \\
\text { yeasts and filamentous } \\
\text { fungi. } \\
\text { Antifungal activity of four } \\
\text { oils (samples 1-4) was } \\
\text { evaluated against yeasts, } \\
\text { Aspergillus and } \\
\text { dermatophyte strains. } \\
\text { Cell viability by MTT assay. }\end{array}$ & $\begin{array}{l}\text { - Four chemotypes were } \\
\text { characterized: carvacrol, } \\
\text { thymol, geranyl } \\
\text { acetate/geraniol and linalool. } \\
\text { The results demonstrated that } \\
\text { the oil with high amounts of } \\
\text { carvacrol, which have } \\
\text { stronger antifungal activity } \\
\text { against dermatophyte strains, } \\
\text { showed no cytotoxic effect, at } \\
\text { concentrations ranging from } \\
0.08 \text { to } 0.16 \mu \mathrm{L} / \mathrm{mL} \text {, for as } \\
\text { long as } 24 \mathrm{~h} \text {. }\end{array}$ & $\begin{array}{l}\text { The potent antifungal activity of } T . \\
\text { zygis subsp. sylvestris oil against } \\
\text { dermatophyte strains was } \\
\text { demonstrated, which justifies the } \\
\text { widespread use of this plant in } \\
\text { traditional medicine. However, further } \\
\text { investigation is needed to evaluate the } \\
\text { suitability of its antifungal properties in } \\
\text { practical applications, namely, in fungal } \\
\text { diseases involving mucosal and } \\
\text { cutaneous infections, and also as an } \\
\text { alternative to synthetic fungicides. }\end{array}$ \\
\hline
\end{tabular}


Table 1. Cont.

\begin{tabular}{|c|c|c|c|c|c|c|c|}
\hline No. & Techniques & Reference & $\begin{array}{l}\text { Type of Skin Infections/ } \\
\text { Fungi Species }\end{array}$ & Essential Oils & Methods & Findings & Conclusion \\
\hline 7. & & [64] & $\begin{array}{c}\text { Dermatophytosis or ring } \\
\text { worm infections (T. rubrum } \\
\text { PTCC 5143, T. } \\
\text { mentagrophytes PTCC 5054, } \\
\text { M. canis PTCC 5069, M. } \\
\text { gypseum PTCC 5070, T. } \\
\text { schoenleinii PTCC 5221, } T \\
\text { verrucosum var. album } \\
\text { PTCC 5056) }\end{array}$ & Satureja khuzistanica & $\begin{array}{l}\text { Chemical profiling using } \\
\text { GC-MS. } \\
\text { Antifungal activities of } \\
\text { extracts and EO were } \\
\text { screened by disc diffusion } \\
\text { method, microbroth } \\
\text { dilution assay and food } \\
\text { poisoning method. } \\
\text { MIC and MFC of extracts } \\
\text { and EO were determined by } \\
\text { broth microdilution assay. }\end{array}$ & $\begin{array}{l}\text { Carvacrol (94.5\%) was the } \\
\text { main component of } S \text {. } \\
\text { khuzistanica EO. } \\
\text { The antifungal activity of } S \text {. } \\
\text { khuzistanica EO (MIC: } 40-190 \\
\mu \mathrm{m} / \mathrm{mL} \text { ) was higher than its } \\
\text { ethanol extract (MIC: } 40-770 \\
\mu \mathrm{m} / \mathrm{mL}) ; \text { while } S \text {. khuzistanica } \\
\text { aqueous extract had no } \\
\text { antifungal activity against } \\
\text { dermatophytes (MIC }= \\
1550-3100 \mu \mathrm{g} / \mathrm{mL}) \text {. }\end{array}$ & $\begin{array}{l}\text { The oil can be used as a topical } \\
\text { treatment for the control or treatment } \\
\text { of skin fungal infections. S. khuzistanica } \\
\text { EO or its ethanol extract can be further } \\
\text { extended to more deeply explore their } \\
\text { antifungal activities. }\end{array}$ \\
\hline 8. & $\begin{array}{l}\text { In vitro-Conventional } \\
\text { technology }\end{array}$ & [65] & $\begin{array}{l}\text { Management of } \\
\text { dermatophytosis (Candida } \\
\text { krusei H9, C. guillermondii } \\
\text { MAT 23, C. albicans ATCC } \\
\text { 10231, C. tropicalis ATCC } \\
\text { 13803, C. parapsilosis ATCC } \\
\text { 90018, C. neoformans CECT } \\
\text { 1078; T. mentagrophytes FF7, } \\
\text { M. canis FF, E. FF9, T. } \\
\text { rubrum CECT 2794, M. } \\
\text { gypseum CECT 2908, A. } \\
\text { flavus F44, A. niger ATCC } \\
\text { 16404, A. fumigatus ATCC } \\
46645\end{array}$ & $\begin{array}{l}\text { D. carota subsp. gummifer } \\
\text { (Syme) Hook.f. }\end{array}$ & $\begin{array}{ll}\text { - } & \text { Chemical profiling } \\
\text { (GC-MS). } \\
\text { - } \\
\text { MICs and MLCs for yeasts } \\
\text { and filamentous fungi were } \\
\text { determined using } \\
\text { macrodilution broth assays. } \\
\text { Anti-inflammatory and } \\
\text { nitric oxide scavenging } \\
\text { activity. } \\
\text { Toxicity was investigated } \\
\text { using MTT assay in several } \\
\text { mammalian cell lines: } \\
\text { macrophages (Raw 264.7), } \\
\text { keratinocytes (HaCat), } \\
\text { hepatocytes (HepG2) and } \\
\text { microglia (N9). }\end{array}$ & $\begin{array}{l}\text { The oil was characterized by } \\
\text { high contents of } \\
\text { monoterpenes ( } 83.9 \% \text { ), the } \\
\text { major compounds being } \\
\text { geranyl acetate (37.0\%) and } \\
\alpha \text {-pinene (30.9\%). The } \\
\text { daucane sesquiterpene, } \\
\text { carotol, was also found in } \\
\text { relatively high amounts } \\
(11.0 \%) \text {. } \\
\text { The oil was particularly active } \\
\text { against dermatophytes and C. } \\
\text { neoformans, with MIC values } \\
\text { ranging from } 0.32 \text { to } 0.64 \\
\mu L / \text { mL. } \\
\text { The oil demonstrated a strong } \\
\text { anti-inflammatory activity by } \\
\text { inhibiting nitric oxide (NO) } \\
\text { production in both } \\
\text { lipopolysacharide } \\
\text { (LPS)-triggered macrophages } \\
\text { and microglia cells. } \\
\text { triggered macrophages and } \\
\text { microglia cells. } \\
\text { We detected a cytotoxic effect } \\
\text { only for the highest } \\
\text { concentrations of the oil, thus } \\
\text { ensuring a safe toxicological } \\
\text { profile at bioactive } \\
\text { concentrations. }\end{array}$ & $\begin{array}{l}\text { These results suggest that } D \text {. carota } \\
\text { subsp. gummifer EO should be explored } \\
\text { as a natural source of antifungal and } \\
\text { anti-inflammatory drugs with potential } \\
\text { application both at the peripheral and } \\
\text { central nervous system levels, thus } \\
\text { supporting in vivo studies focused in } \\
\text { the management of dermatophytosis } \\
\text { and/or inflammatory-related diseases. }\end{array}$ \\
\hline
\end{tabular}


Table 1. Cont.

Methods

Findings

Conclusion

No. Technique Fungi Species

Essential Oils

(n)

- The main compounds of $S$.

officinalis oils were 1,8-cineole

Various skin diseases

C. albicans ATCC 10231, C.

parapsilosis ATCC 90018, $C$

tropicalis ATCC 13803, C.

geoillermondi MAT2, $C$

krusei $\mathrm{HO}$, A niger ATCC

16404, A. fumigatus ATCC

9. In vitro-Conventional

[66] 46645, A. flavus F44, $E$.

floccosum $\mathrm{FF}$, $T$.

mentagrophytes FF7, $M$.

canis FF1, T. rubrum CECT

2794, M. gypseum CECT

2908, T. mentagrophytes var.

interdigitale CECT 2958

and T. verrucosum $\mathrm{CEC}$

Salvia officinalis $\mathrm{L}$.

- Chemical profiling by GC

and GC-MS

evaluated against yeasts, dermatophyte and

Aspergillus strains by broth

macrodilution methods.

- Cell viability by MTT assay.

Anti-inflammatory

potential was evaluated by

measuring $\mathrm{NO}$ productio

use macrophages.

The dermatophyte strains

showed more sensitivity to

these oils when compared

with Candida and Aspergill

strains, particularly for $T$.

MIC of $0.64 \mu \mathrm{L} / \mathrm{mL}$.

- Among the tested yeasts,

Cryptococcus neoformans

showed more sensitivity with

MIC of $0.64 \mu \mathrm{L} / \mathrm{mL}$

- The oils revealed antifungal

activity against dermatophyte

strains and significantly

inhibited NO productio

stimulated by LPS in

macrophages, without

affecting cell viability, in

$0.64 \mu \mathrm{L} / \mathrm{mL}$.

- The EOs showed the most interesting bioactivity on the

Various skin diseases (C. rubrum SNB-TR1, T.

soudanense SNB-TS1, T.

Abies cilicica, Cupressu sempervirens, Juniperus Cedrus liberions oxycedrus, Cellus libin and clupressis
Chemical profiling by GC and GC-MS

- The MICs of thes EOs were determined using the broth determined using the broth dermatophytes species (MIC

values $32-64 \mu \mathrm{g} / \mathrm{mL}$.

- $\quad$ Each of the major compound of C. macrocarpa, as well as artificially reconstructed $\mathrm{EO}$ were tested on T.rubrum, minor components to the overall activity. The main components were $\alpha$-pinen and sabinene.
- This is the first report addressing the S. officinalis oil. These findings concentrations of S. officinalis oils do not affect mammalian macrophages or keratinocytes viability making them suitable for use in skin care formulations for cosmetic and pharmaceutical purposes. interesting antimicrobial activity, particularly against Trichophyton
species. These EOs should therefore considered for a possible integration in antimicrobial preparations intended to be used in the treatment of superficial 
Table 1. Cont.

\begin{tabular}{|c|c|c|c|c|c|c|c|}
\hline No. & Techniques & Reference & $\begin{array}{l}\text { Type of Skin Infections/ } \\
\text { Fungi Species }\end{array}$ & Essential Oils & Methods & Findings & Conclusion \\
\hline 11. & $\begin{array}{l}\text { In vitro-Conventional } \\
\text { technology }\end{array}$ & [68] & $\begin{array}{l}\text { Contact dermatitis and } \\
\text { skin infections } \\
\text { (C. krusei H9, C. } \\
\text { guillermondii MAT23, C. } \\
\text { albicans ATCC } 10231, C \text {. } \\
\text { tropicalis ATCC } 13803, \text { C. } \\
\text { parapsilosis ATCC } 90018, C \text {. } \\
\text { neoformans CECT 1078, E. } \\
\text { floccosum FF9, T. } \\
\text { mentagrophytes FF7, M. } \\
\text { canis FF1, T. rubrum CECT } \\
\text { 2794, Microsporum gypseum } \\
\text { CECC 2908, A. flavus F44, } \\
\text { A. niger ATCC 16404, A. } \\
\text { fumigatus ATCC 46645) }\end{array}$ & Distichoselinum tenuifolium & $\begin{array}{l}\text { - Chemical profiling by GC } \\
\text { and GC-MS. } \\
\text { Antifungal activity MIC } \\
\text { and MLC were evaluated } \\
\text { against yeasts, } \\
\text { dermatophyte and } \\
\text { Aspergillus strains. } \\
\text { - Cell viability by MTT assay. } \\
\text { Anti-inflammatory } \\
\text { potential was evaluated by } \\
\text { measuring NO production } \\
\text { induced by LPS, in the } \\
\text { absence or in the presence } \\
\text { of the oil, in a mouse } \\
\text { macrophage cell line. }\end{array}$ & $\begin{array}{l}\text { The oils are predominantly } \\
\text { composed of monoterpene } \\
\text { hydrocarbons, with myrcene } \\
\text { being the main compound } \\
\text { (47.7-84.6\%). } \\
\text { The oils revealed significant } \\
\text { antifungal activity against } C \text {. } \\
\text { neoformans and dermatophyte } \\
\text { strains, and significantly } \\
\text { inhibited NO production } \\
\text { stimulated by LPS in } \\
\text { macrophages without } \\
\text { affecting cell viability at } \\
\text { concentrations ranging from } \\
0.64 \mathrm{~L} / \mathrm{mL} \text { to } 1.25 \mathrm{~L} / \mathrm{mL} \text {. }\end{array}$ & $\begin{array}{l}\text { These findings add significant } \\
\text { information to the pharmacological } \\
\text { activity of } D \text {. tenuifolium EO, } \\
\text { specifically, to its antifungal and } \\
\text { anti-inflammatory properties, thus } \\
\text { justifying and reinforcing the use of } \\
\text { this plant in traditional medicine, } \\
\text { mainly for the treatment of contact } \\
\text { dermatitis, characterized by a strong } \\
\text { inflammatory component, and skin } \\
\text { infections. Therefore, their beneficial } \\
\text { effects and use in disease prevention, } \\
\text { especially when related to fungal } \\
\text { infections and inflammation, should be } \\
\text { explored in more depth. }\end{array}$ \\
\hline 12. & $\begin{array}{l}\text { In vitro-Conventional } \\
\text { technology }\end{array}$ & [69] & $\begin{array}{l}\text { Skin infections (T. rubrum } \\
\text { and T. mentagrophytes) }\end{array}$ & $\begin{array}{l}\text { Agathosma betulina and } \\
\text { Coleonema album }\end{array}$ & $\begin{array}{ll}\text { - } & \text { EOs analysis by GC-MS. } \\
\text { Antifungal capacity was } \\
\text { evaluated by volatile } \\
\text { release plate method. } \\
\text { The mode of action of the } \\
\text { EOs volatiles was } \\
\text { elucidated using SEM. }\end{array}$ & 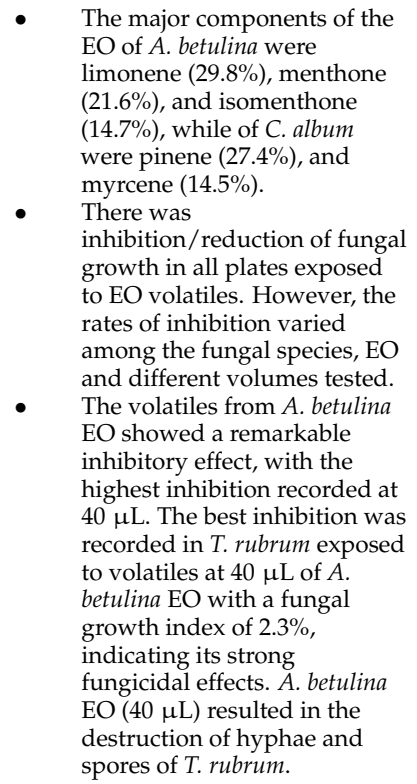 & $\begin{array}{l}\text { - The EO volatiles of } A \text {. betulina had good } \\
\text { inhibitory effects on the mycelia } \\
\text { growth of T. rubrum and T. } \\
\text { mentagrophytes. The fungicidal effect of } \\
\text { EO volatiles on T. rubrum was } \\
\text { particularly noteworthy. The mode of } \\
\text { action of } A \text {. betulina EO volatiles on the } \\
\text { growth of T. rubrum mycelia was } \\
\text { shown to be through the inhibition of } \\
\text { spore growth and production and } \\
\text { alteration of the morphology by } \\
\text { destruction of the hyphae and spores. } \\
\text { EO induced different actions on the } \\
\text { mycelia at different concentrations. } \\
\text { Limonene and menthone, as the major } \\
\text { components of } A \text {. betulina EO, are } \\
\text { probably responsible for this activity, as } \\
\text { they have been previously shown to } \\
\text { possess antifungal activity. The } \\
\text { remarkable activity recorded in this } \\
\text { study gives an insight into the potential } \\
\text { of } A \text {. betulina EO as a skin antifungal. }\end{array}$ \\
\hline
\end{tabular}


Table 1. Cont.

\begin{tabular}{|c|c|c|c|c|c|c|c|}
\hline No. & Techniques & Reference & $\begin{array}{l}\text { Type of Skin Infections/ } \\
\text { Fungi Species }\end{array}$ & Essential Oils & Methods & Findings & Conclusion \\
\hline 13. & & [70] & $\begin{array}{l}\text { Skin infections (T. rubrum } \\
\text { and T. mentagrophytes) }\end{array}$ & C. album and C. pulchellum & $\begin{array}{ll}-\quad & \text { EOs analysis by GC-MS. } \\
\text { Antifungal capacity of EOs } \\
\text { was evaluated by volatile } \\
\text { release plate method. }\end{array}$ & 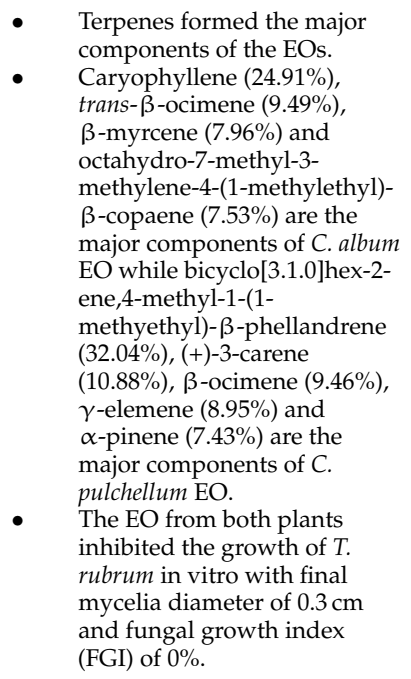 & $\begin{array}{l}\text { - This study revealed the therapeutic } \\
\text { value of C. pulchellum. Coleonema album } \\
\text { and C. pulchellum should be considered } \\
\text { as potential plants for use in skin } \\
\text { ointment. However, toxicity studies of } \\
\text { C. pulchellum EO need to be carried out } \\
\text { in order to ensure their safety for } \\
\text { topical application. }\end{array}$ \\
\hline 15. & & [72] & $\begin{array}{c}\text { Skin infections } \\
\text { (C. albicans, Candida } \\
\text { stellatoidea and Candida } \\
\text { torulopsis) }\end{array}$ & Physalis angulata & $\begin{array}{l}\text { - Antifungal activity by agar } \\
\text { well diffusion method. }\end{array}$ & $\begin{array}{l}\text { C. torulopsis, C. stellatoidea and } \\
\text { C. albicans were susceptible to } \\
\text { the EO from the aerial and } \\
\text { root part of the plant (MIC: } \\
3.75-4.0 \mathrm{mg} / \mathrm{mL} \text { ). }\end{array}$ & $\begin{array}{l}\text { - The observed inhibition of selected } \\
\text { fungi by oils of } P \text {. angulata makes it a } \\
\text { promising antimicrobial agent. }\end{array}$ \\
\hline
\end{tabular}


Table 1. Cont.

\begin{tabular}{|c|c|c|c|c|c|c|c|}
\hline No. & Techniques & Reference & $\begin{array}{l}\text { Type of Skin Infections/ } \\
\text { Fungi Species }\end{array}$ & Essential Oils & Methods & Findings & Conclusion \\
\hline 16. & $\begin{array}{l}\text { In vitro_Conventional } \\
\text { technology }\end{array}$ & [73] & $\begin{array}{l}\text { Dermatophytes and fungi } \\
\text { infections } \\
\text { (Microsporum gypseum, M. } \\
\text { canis, Arthroderma cajetani, } \\
\text { T. mentagrophytes, } T . \\
\text { tonsurans, E. floccosum, } \\
\text { Botrytis cinerea, Pythium } \\
\text { ultimum) }\end{array}$ & Marrubium vulgare $\mathrm{L}$. & $\begin{array}{l}\text { EO analysis by GC/MS. } \\
\text { Antifungal activity by } \\
\text { transplanting mycelium } \\
\text { disks from a single culture } \\
\text { in stationary phase. }\end{array}$ & $\begin{array}{l}\text { - EO was high in eugenol } \\
(15.29 \%) \text {. } \\
\text { The antifungal activity of } \\
\text { different extracts, marrubiin } \\
\text { and EO at two concentrations } \\
\text { (20 and } 100 \mu \mathrm{\mu g} / \mathrm{mL}) \text { showed } \\
\text { about } 50 \% \text { inhibition for } T \text {. } \\
\text { mentagrophytes and } E \text {. } \\
\text { floccosum for marrubiin at } 100 \\
\mu \mathrm{m} / \mathrm{mL} \text {. } \\
\text { The antiphytopathogenic } \\
\text { activity was also evaluated; } \\
\text { only marrubiin had activity } \\
\text { against } B \text {. cinerea at the } \\
\text { highest dose }(32.40 \%) \text {. }\end{array}$ & $\begin{array}{l}\text { M. vulgare and marrubiin can be used } \\
\text { as natural antioxidants and antifungal } \\
\text { agents for the treatment of skin } \\
\text { dermatophyte infections. } \\
\text { Complementary investigations should } \\
\text { be conducted to assess the effectiveness } \\
\text { of this compound. }\end{array}$ \\
\hline 17. & & [74] & $\begin{array}{l}\text { Skin infections } \\
\text { (C.a albicans 1, C. albicans 2, } \\
\text { T. rubrum 1, T. rubrum 2, T. } \\
\text { violaceum, and T. } \\
\text { soudanensis) }\end{array}$ & $\begin{array}{l}\text { Eugenia caryophylla and } \\
\text { Mentha sp cf piperita }\end{array}$ & $\begin{array}{l}\text { - } \quad \text { EOs analysis by GC-MS. } \\
\text { Antifungal activity by broth } \\
\text { microdilution method } \\
\text { M27-A3 and M38-A. }\end{array}$ & $\begin{array}{l}\text { E. caryophylla was mainly } \\
\text { composed of eugenol }(80.0 \%) \text {, } \\
\text { square-caryophyllene }(8.3 \%), \\
\text { and eugenol acetate }(6.7 \%) \\
\text { while } M \text {. ss cf piperita was } \\
\text { characterized by piperitone } \\
(67.5 \%), \text { menthol }(10.0 \%) \text { and } \\
\text { beta-phellandrene }(5.8 \%) \text {. } \\
\text { E. caryophylla EO exhibited the } \\
\text { highest antifungal activity } \\
\text { with MIC and MFC of } 0.25 \\
\mu \mathrm{L} / \mathrm{mL} \text { and } 0.125 \mu \mathrm{L} / \mathrm{mL} \text { for } \\
\text { filamentous fungi and MIC of } \\
0.5 \mu \mathrm{mL} \text { m for both yeast } \\
\text { strains while MFC value was } \\
1 \mu \mathrm{m} / \mathrm{mL} \text { for one yeast strain } \\
\text { and not determined for the } \\
\text { second. } \\
\text { MFC of } M \text {. sp cf piperita EO } \\
\text { showed weak activity with a } \\
\text { MIC of } 2.5 \mu \mathrm{L} / \mathrm{mL} \text { on } \\
\text { Tricophyton strains, while no } \\
\text { activity was exhibited on } C . \\
\text { albicans strains. }\end{array}$ & $\begin{array}{l}\text { The results of this work can be used to } \\
\text { confirm their traditional uses and can } \\
\text { also be proposed as natural ingredients } \\
\text { to some industries to treat superficial } \\
\text { infections. }\end{array}$ \\
\hline
\end{tabular}


Table 1. Cont.

\begin{tabular}{|c|c|c|c|c|c|c|c|}
\hline No. & Techniques & Reference & $\begin{array}{l}\text { Type of Skin Infections/ } \\
\text { Fungi Species }\end{array}$ & Essential Oils & Methods & Findings & Conclusion \\
\hline 18. & $\begin{array}{l}\text { In vitro-Conventional } \\
\text { technology }\end{array}$ & [75] & $\begin{array}{l}\text { Skin diseases } \\
\text { (E. floccosum, M. canis, M. } \\
\text { gypseum, T. mentagrophytes, } \\
\text { T. mentagrophytes var. } \\
\text { interdigitale, T. rubrum, } T \text {. } \\
\text { verrucosum, C. albicans, C. } \\
\text { guilliermondiil, C. krusei, C. } \\
\text { parapsilosis, C. tropicalis, C. } \\
\text { neoformans, A. flavus, A. } \\
\text { fumigatus, A. niger). }\end{array}$ & $\begin{array}{l}\text { Juniperus communis subsp. } \\
\text { alpina (Suter) Celak }\end{array}$ & $\begin{array}{l}\text { EO analysis by GC-MS. } \\
\text { Antifungal activity by broth } \\
\text { macrodilution method. } \\
\text { Cytotoxicity was tested in a } \\
\text { human keratinocyte cell } \\
\text { line (HaCaT) through MTT } \\
\text { assay. }\end{array}$ & $\begin{array}{l}\text { - J. communis subsp. alpina } \\
\text { needles EO was } \\
\text { predominantly composed of } \\
\text { monoterpene hydrocarbons } \\
\text { (78.4\%), with the main } \\
\text { compounds being sabinene } \\
(26.2 \%), \alpha-\text { pinene }(129 \%) \text { and } \\
\text { limonene }(10.4 \%) \text {. } \\
\text { Antifungal activity } \\
\text { demonstrated the potential of } \\
\text { needle oil against } \\
\text { dermatophytes, particularly } \\
\text { for } M \text {. canis and T. rubrum, } \\
\text { with MIC and MLC of } 0.32 \\
\mu \mathrm{L} / \mathrm{mL} \text {. } \\
\text { Evaluation of cell viability } \\
\text { showed no significant } \\
\text { cytotoxicity in HaCaT } \\
\text { keratinocytes at } \\
\text { concentrations between } 0.32 \\
\text { and } 0.64 \mu \mathrm{L} / \mathrm{mL} \text {. }\end{array}$ & $\begin{array}{l}\text { - These results show that it is possible to } \\
\text { find appropriate doses of J. communis } \\
\text { subsp. alpina oil with both antifungal } \\
\text { activity and a very low detrimental } \\
\text { effect on keratinocytes. }\end{array}$ \\
\hline 19. & & [76] & $\begin{array}{l}\text { Skin infection } \\
\text { sporotrichosis (Sporothrix } \\
\text { schenckii fungus) }\end{array}$ & Turmeric (Curcuma longa) & $\begin{array}{l}\text { EO analysis by GC-MS. } \\
\text { Antifungal activity by disc } \\
\text { diffusion method. }\end{array}$ & $\begin{array}{l}\text { - GC MS analysis revealed the } \\
\text { presence of more than } 20 \\
\text { component, including } \\
\text { Ar-turmerone and dehydro } \\
\text { Ar-turmerone. } \\
\text { Activity against } S \text {. schenckii } \\
\text { fungus showed zone of } \\
\text { growth inhibition was } 9 \mathrm{~mm} \\
\text { by the sample oil after } 8 \text { days } \\
\text { and } 11 \mathrm{~mm} \text { after } 10 \text { days. }\end{array}$ & - No conclusion was presented. \\
\hline
\end{tabular}


Table 1. Cont.

\begin{tabular}{|c|c|c|c|c|c|c|c|}
\hline No. & Techniques & Reference & $\begin{array}{l}\text { Type of Skin Infections/ } \\
\text { Fungi Species }\end{array}$ & Essential Oils & Methods & Findings & Conclusion \\
\hline 20. & & [77] & $\begin{array}{l}\text { Skin infections (T. rubrum } \\
\text { and T. mentagrophytes) }\end{array}$ & $\begin{array}{l}\text { Lavandula luisieri and } \\
\text { Cymbopogon citratus }\end{array}$ & $\begin{array}{ll}- & \text { EOs analysis by GC-MS. } \\
\text { - } & \text { Antifungal activity. } \\
\text { Inhibition of conidial } \\
\text { germination and antifungal } \\
\text { drug/EOs combination } \\
\text { assay. }\end{array}$ & $\begin{array}{l}\text { EOs were characterized by a } \\
\text { high amount of oxygenated } \\
\text { monoterpenes in their } \\
\text { composition. } \\
\text { Strong antifungal activity was } \\
\text { observed for the majority of } \\
\text { clinical strains, and fungicidal } \\
\text { activity was demonstrated. } \\
\text { Positive interaction between } L \text {. } \\
\text { luisieri EO combined with } \\
\text { terbinafine was observed } \\
\text { against terbinafine-resistant } \\
\text { strain (Tr ATCC MYA-4438). } \\
\text { Significant reduction of the } \\
\text { germination was observed } \\
\text { above } 100 \mu \mathrm{gg} / \mathrm{mL} . \\
\text { Both oils were safe to } \\
\text { macrophage mammalian cells } \\
\text { at tested concentration. }\end{array}$ & $\begin{array}{l}\text { - This study describes the antifungal } \\
\text { activity of L. luisieri and C. citratus EOs } \\
\text { against dermatophytes, which could be } \\
\text { useful in the design of new } \\
\text { formulations for topical treatments. } \\
\text { This study also proposes L. luisieri as a } \\
\text { suitable oil for combined treatment } \\
\text { against terbinafine-resistant fungal } \\
\text { strains, although further in vivo } \\
\text { experiments are needed to evaluate the } \\
\text { therapeutic efficacy and safety of the } \\
\text { EOs in combination with antifungal } \\
\text { drugs. }\end{array}$ \\
\hline 21. & $\begin{array}{l}\text { In vitro-Conventional } \\
\text { technology }\end{array}$ & [78] & $\begin{array}{c}\text { Skin diseases } \\
\text { (Propionibacterium acnes, } \\
\text { Malassezia spp., C. albicans } \\
\text { and Trichophyton spp.) }\end{array}$ & $\begin{array}{l}\text { Nine EOs } \\
\text { (Cyperus scariosus R. Br., } \\
\text { Syzgium aromaticum L. } \\
\text { Merret L.M. Perry, Carum } \\
\text { carvi L., Coriandrum } \\
\text { sativum L., Boswellia serrata } \\
\text { Roxb. Ex Colebr., Syzgium } \\
\text { cumini } \text { L. Skeels, Elettaria } \\
\text { cardamom L. Maton, } \\
\text { Occimum sanctum L. and } \\
\text { Piper nigrum L.) }\end{array}$ & $\begin{array}{l}\text { EOs analysis by GC-MS. } \\
\text { Antifungal activity by MIC } \\
\text { (microbroth dilution) and } \\
\text { zone of inhibition } \\
\text { (ZOI) test. } \\
\text { Synergistic activity by Etest } \\
\text { and ZOI. }\end{array}$ & 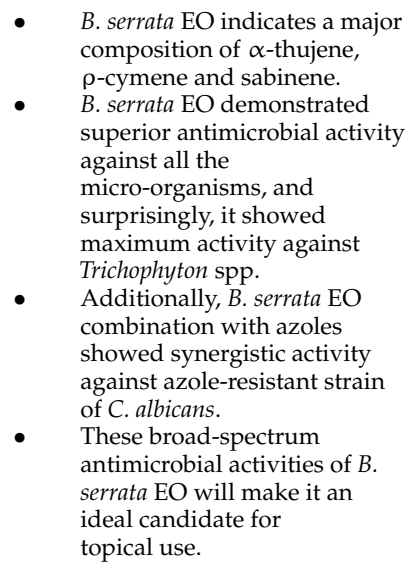 & $\begin{array}{l}\text { B. serrata EO is a plausible therapeutic } \\
\text { agent for the management of skin, scalp } \\
\text { and nail infections. Further studies are } \\
\text { needed to determine the mode of action } \\
\text { and its safety for clinical use, and an } \\
\text { analysis should be undertaken of its } \\
\text { individual constituents. }\end{array}$ \\
\hline
\end{tabular}


Table 1. Cont

\begin{tabular}{|c|c|c|c|c|c|c|c|}
\hline No. & Techniques & Reference & $\begin{array}{l}\text { Type of Skin Infections/ } \\
\text { Fungi Species }\end{array}$ & Essential Oils & Methods & Findings & Conclusion \\
\hline 22. & $\begin{array}{l}\text { In vitro-Conventional } \\
\text { technology }\end{array}$ & [79] & $\begin{array}{l}\text { Skin infections by yeast } \\
\text { (C. albicans 31, C. tropicalis } \\
\text { 32, C. glabrata 33, C. glabrata } \\
\text { 35 and C. glabrata 38) }\end{array}$ & $\begin{array}{l}\text { Six commercial lemon EOs } \\
\text { (ETJA, Vera-Nord, } \\
\text { Avicenna-Oil, Dufti by } \\
\text { Gies, Art, and Croce } \\
\text { Azzurra }\end{array}$ & $\begin{array}{ll}- & \text { EOs analysis by GC-MS. } \\
\text { - } & \text { Antifungal activity by MIC. } \\
\text { GC-MS analysis. }\end{array}$ & $\begin{array}{l}\text { - Various lemon EOs had } \\
\text { different chemical } \\
\text { compositions, but mostly, they } \\
\text { contained almost exclusively } \\
\text { terpenes and oxygenated } \\
\text { terpenes. } \\
\text { The tests show that the } \\
\text { antifungal potential of lemon } \\
\text { EOs against Candida yeast } \\
\text { strains is related to the high } \\
\text { content of monoterpenoids } \\
\text { and the type of strains. } \\
\text { From six tested commercial } \\
\text { oils, only four (ETJA, } \\
\text { Vera-Nord, Avicenna-Oil and } \\
\text { Aromatic Art) showed } \\
\text { antifungal potential against } \\
\text { three Candida species } \\
\text { (C. albicans, C. tropicalis and } \\
\text { C. glabrata). } \\
\text { Vera-Nord and Avicenna-Oil } \\
\text { showed the best activity, and } \\
\text { effectively inhibited the } \\
\text { growth of the C. albicans strain } \\
\text { across the full range of } \\
\text { concentrations used. }\end{array}$ & $\begin{array}{l}\text { - This study characterized lemon EOs, } \\
\text { which could be used as natural } \\
\text { remedies against candidiasis caused by } \\
\text { C. albicans. }\end{array}$ \\
\hline 23. & & [80] & $\begin{array}{c}\text { Skin diseases } \\
\text { (M. canis KCTC 6348, 6349, } \\
\text { 6591, T. rubrum KCTC 6345, } \\
\text { 6352, 6375, T. } \\
\text { mentagrophytes KCTC } 6077 \\
\text { and 6085) }\end{array}$ & Lonicera japonica Thunb. & $\begin{array}{l}\text { - } \quad \begin{array}{l}\text { Antidermatophytic activity } \\
\text { of EO by poisoned food } \\
\text { technique. }\end{array} \\
\text { MIC by agar dilution } \\
\text { method. } \\
\text { - } \quad \begin{array}{l}\text { Spore germination and } \\
\text { growth kinetics assay. }\end{array}\end{array}$ & $\begin{array}{l}\text { - L. japonica EO (1000 ppm) } \\
\text { revealed 55.1-10.3\% } \\
\text { antidermatophytic effect } \\
\text { against Microsporum canis } \\
\text { KCTC 6348, 6349, 6591, T. } \\
\text { rubrum KCTC 6345, 6352, } \\
\text { 6375, T. mentagrophytes KCTC } \\
\text { 6077 and 6085, respectively, } \\
\text { with MIC ranging from } \\
\text { 62.5-500 } \mu \mathrm{g} / \mathrm{mL} \text {. } \\
\text { The oil had strong detrimental } \\
\text { effect on the spore } \\
\text { germination of all the tested } \\
\text { dermatophytes, as well as } \\
\text { concentration and } \\
\text { time-dependent kinetic } \\
\text { inhibition of } M \text {. canis } \\
\text { KCTC 6348. }\end{array}$ & $\begin{array}{l}\text { The results demonstrated that } L \text {. } \\
\text { japonica oil could be a potential source } \\
\text { of natural fungicides to protect human } \\
\text { and animals from fungal infections. }\end{array}$ \\
\hline
\end{tabular}


Table 1. Cont.

\begin{tabular}{|c|c|c|c|c|c|c|c|}
\hline No. & Techniques & Reference & $\begin{array}{l}\text { Type of Skin Infections/ } \\
\text { Fungi Species }\end{array}$ & Essential Oils & Methods & Findings & Conclusion \\
\hline 24. & $\begin{array}{l}\text { In vitro-Conventional } \\
\text { technology }\end{array}$ & [81] & $\begin{array}{c}\text { Skin diseases (Fusarium } \\
\text { oxysporum, } \\
\text { T. rubrum and } T . \\
\text { mentagrophytes) }\end{array}$ & Seventeen EOs & $\begin{array}{l}\text { - } \quad \text { EOs analysis by GC-MS } \\
\text { and GC-FID. } \\
\text { Antifungal activity by } \\
\text { M38-A protocol. } \\
\text { Cytotoxicity assay using } \\
\text { MTT technique. }\end{array}$ & 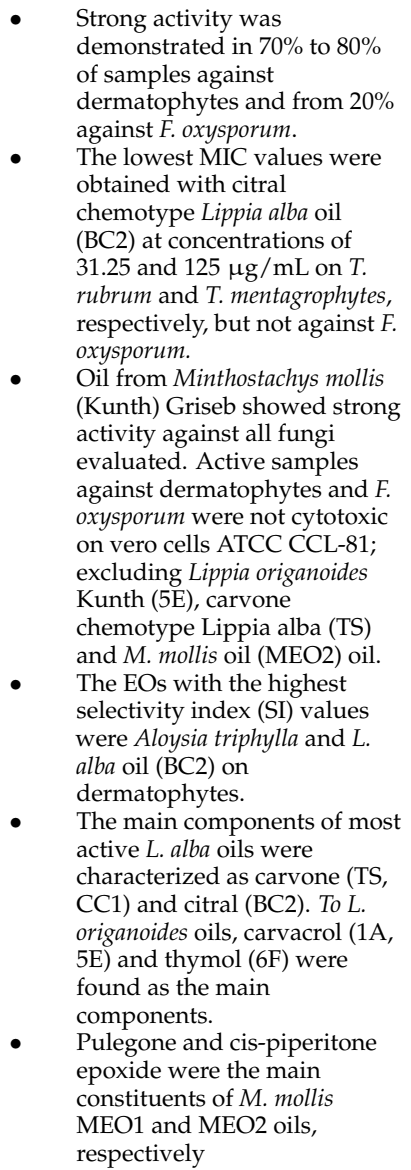 & $\begin{array}{l}\text { - The main components in these EOs } \\
\text { may be responsible for their antifungal } \\
\text { activity. This finding is very important, } \\
\text { because it confirms the potential of } \\
\text { these EOs as a source of new } \\
\text { antidermatophytes. }\end{array}$ \\
\hline
\end{tabular}


Table 1. Cont.

\begin{tabular}{|c|c|c|c|c|c|c|c|}
\hline No. & Techniques & Reference & $\begin{array}{l}\text { Type of Skin Infections/ } \\
\text { Fungi Species }\end{array}$ & Essential Oils & Methods & Findings & Conclusion \\
\hline 25. & $\begin{array}{l}\text { In vitro-Conventional } \\
\text { technology }\end{array}$ & [82] & $\begin{array}{l}\text { Pityriasis versicolor } \\
\text { (Malassezia furfur) }\end{array}$ & $\begin{array}{l}\text { Citrus lemon (lemon) and } \\
\text { Citrus sinensis (orange) }\end{array}$ & $\begin{array}{l}\text { - Antifungal activity by disc } \\
\text { diffusion and microdilution } \\
\text { methods. }\end{array}$ & $\begin{array}{l}\text { - In screening lemon and } \\
\text { orange oil by disc diffusion } \\
\text { method, the diameter of } \\
\text { inhibition zone was found to } \\
\text { be } 50 \text { and } 20 \mathrm{~mm} \text {, i.e., greater } \\
\text { than that of reference } \\
\text { antibiotics, that is, } \\
\text { gentamycin and streptomycin, } \\
\text { which showed } 16.5 \text { and } 17 \\
\text { mm, respectively. } \\
\text { MIC of lemon and orange oil } \\
\text { against } M . \text { furfur was found to } \\
\text { be } 0.8 \text { and } 2.2 \mu \mathrm{L} / \mathrm{mL} \text {. }\end{array}$ & $\begin{array}{l}\text { The findings in this study support the } \\
\text { use of lemon and orange oil as a } \\
\text { traditional herbal medicine for the } \\
\text { control of } P \text {. versicolor infection in the } \\
\text { skin. }\end{array}$ \\
\hline 26. & & [83] & $\begin{array}{l}\text { Skin infections (C. albicans, } \\
\text { C. dubliniensis, C. glabrata, } \\
\text { C. guilliermondii, C. } \\
\text { parapsilosis, C. tropicalis, C. } \\
\text { neoformans, Sacharomyces } \\
\text { cerevisiae, A. fumigatus, } \\
\text { A. flavus, A. niger, T. } \\
\text { rubrum, M. canis, Fonsecaea } \\
\text { pedrosoi, Pseudallescheria } \\
\text { boydii, Fusarium solani, S. } \\
\text { schenckii) } \\
\end{array}$ & $\begin{array}{l}\text { Tropaeolum pentaphyllum } \\
\text { Lam. tubers }\end{array}$ & $\begin{array}{l}\text { - } \quad \text { EO analysis by GC-MS. } \\
\text { Antifungal activity by MIC. }\end{array}$ & $\begin{array}{l}\text { - GC-MS analysis revealed that } \\
\text { the major EO constituent is } \\
\text { benzyl isothiocyanate. } \\
\text { The strongest effects against } \\
\text { Candida spp. and } \\
\text { dermatophytes were observed } \\
\text { for the EO, with MIC well } \\
\text { below } 200 \mu \mathrm{g} / \mathrm{mL} \text {. }\end{array}$ & $\begin{array}{l}\text { Overall, the results support the use of } \\
\text { the plant for the tratment of skin } \\
\text { infections, and reveal the main active } \\
\text { compounds. }\end{array}$ \\
\hline 27. & $\begin{array}{l}\text { In vitro-Conventional } \\
\text { technology }\end{array}$ & [84] & $\begin{array}{l}\text { Skin infections (T. rubrum } \\
\text { and C. albicans) }\end{array}$ & Twenty-nine oils & $\begin{array}{l}\text { Antifungal activity by } \\
\text { agar-well diffusion and } \\
\text { MIC method. }\end{array}$ & $\begin{array}{l}\text { - Most of the EOs showed } \\
\text { relatively high antimicrobial } \\
\text { activity against all the tested } \\
\text { organisms. } \\
\text { The maximum antimicrobial } \\
\text { activity was shown by } \\
\text { Calotropis gigantea, followed } \\
\text { by Semecarpus anacardium, } \\
\text { Azadirachta indica, Datura } \\
\text { stromium, Coriandrum sativum, } \\
\text { Luffa acutangula, Momordica } \\
\text { cymbalaria, Gliricidia sepium, } \\
\text { Hyptis sauveolens and O. } \\
\text { sanctum against the tested } \\
\text { fungi. } \\
\text { C. gigantae showed good } \\
\text { antimicrobial activity against } \\
\text { tested fungi, with MIC values } \\
\text { ranging from } 0.62 \text { to } 40 \\
\text { mg/mL, determined using } \\
\text { inhibitory zone estimation. }\end{array}$ & $\begin{array}{l}\text { The obtained results suggest that } C \text {. } \\
\text { gigantae has antimicrobial activity. } \\
\text { These results support the hypothesis } \\
\text { that the plant oil can be used to cure } \\
\text { skin diseases, and may have a role as a } \\
\text { pharmaceutical compound and as a } \\
\text { preservative. }\end{array}$ \\
\hline
\end{tabular}


Table 1. Cont.

\begin{tabular}{|c|c|c|c|c|c|c|c|}
\hline No. & Techniques & Reference & $\begin{array}{l}\text { Type of Skin Infections/ } \\
\text { Fungi Species }\end{array}$ & Essential Oils & Methods & Findings & Conclusion \\
\hline 28. & $\begin{array}{l}\text { In vitro-Nonconventional } \\
\text { technology }\end{array}$ & [85] & $\begin{array}{l}\text { Skin infections (Candida } \\
\text { pseudotropicalis) }\end{array}$ & $\begin{array}{l}\text { Lippia multiflora } \\
\quad \text { (lippia oil) }\end{array}$ & $\begin{array}{l}\text { Different concentrations of } \\
\text { the oil were incorporated } \\
\text { into six different ointment } \\
\text { bases. } \\
\text { Tween } 80 \text { was incorporated } \\
\text { at different concentrations } \\
\text { into ointments containing } \\
10 \% \text { w } w \text { lippia oil; a } \\
\text { concentration at which } \\
\text { minimum antimicrobial } \\
\text { activity was observed in the } \\
\text { ointment bases. } \\
\text { The viscosity, spreadability } \\
\text { and stability of the } \\
\text { formulations were } \\
\text { determined. } \\
\text { Antimicrobial activities of } \\
\text { lippia oil in the } \\
\text { formulations were } \\
\text { determined against selected } \\
\text { bacteria and fungi using the } \\
\text { agar diffusion assay } \\
\text { method; } 10 \% \text { w/w salicylic } \\
\text { acid formulations were } \\
\text { used as reference products. }\end{array}$ & $\begin{array}{l}\text { - } \quad \text { Incorporation of lippia oil into } \\
\text { the ointment bases led to } \\
\text { reduction in their viscosity } \\
\text { with increase in spreadability. } \\
\text { None of the formulations } \\
\text { showed antimicrobial activity } \\
\text { at lippia oil content } \leq 5 \% \text { s } w / w \text {. } \\
\text { Inclusion of Tween } 80 \text { in the } \\
\text { formulations significantly } \\
\text { increased the antimicrobial } \\
\text { activities of the oil }(p<0.05) \text {. } \\
\text { The antimicrobial activities of } \\
10 \% w / w \text { lippia oil formulated } \\
\text { in absorption bases } \\
\text { containing } 6 \% \text { w } w \text { Tween } 80 \\
\text { were significantly higher }(p< \\
\text { 0.05) than those formulated in } \\
\text { hydrophobic bases. } \\
\text { Lippia oil ointment } \\
\text { formulations showed greater } \\
\text { antimicrobial activities than } \\
\text { salicylic acid ointments. Two } \\
\text { of the lippia oil ointment } \\
\text { formulations bled when } \\
\text { subjected to centrifugal force. }\end{array}$ & $\begin{array}{l}\text { - Ointment formulations of lippia oil } \\
(10 \% \text { w/w) in absorption base (hydrous } \\
\text { wool fat ointment BP or simple } \\
\text { ointment BP) containing } 6 \% \text { w/w Tween } \\
80 \text { were found to be stable and very } \\
\text { effective at inhibiting the growth of } \\
\text { selected pathogens implicated in skin } \\
\text { infections. }\end{array}$ \\
\hline 29. & $\begin{array}{l}\text { In vitro-Nonconventional } \\
\text { technology }\end{array}$ & [56] & $\begin{array}{c}\text { Different skin infecting } \\
\text { pathogens (C. albicans, } A \text {. } \\
\text { niger })\end{array}$ & Piper betle & $\begin{array}{l}\text { Agar well disc diffusion } \\
\text { method for zone of } \\
\text { inhibition and broth } \\
\text { dilution method for MIC. } \\
\text { Gels were formulated using } \\
\text { different polymers like } \\
\text { hydroxy propyl methyl } \\
\text { cellulos (HPMC), Carbopol } \\
\text { 934, sodium carboxy } \\
\text { methyl cellulose (sodium } \\
\text { CMC), and sodium } \\
\text { alginate. } \\
\text { Formulation was evaluated } \\
\text { for various } \\
\text { physico-chemical } \\
\text { parameters like pH, } \\
\text { viscosity, consistency, } \\
\text { homogeneity, spreadability, } \\
\text { skin irritation test and } \\
\text { stability studies. }\end{array}$ & $\begin{array}{l}\text { C. albicans showed maximum } \\
\text { sensitivity to the oil that was } \\
24 \mathrm{~mm} \text { at } 20 \mu \mathrm{L} \text { and } 20 \mathrm{~mm} \text { at } \\
20 \mu \mathrm{L} \text { for } A \text {. niger. } \\
\text { Zone of inhibition of oil was } \\
\text { not much affected by } \\
\text { incorporation into a gel, as } \\
\text { confirmed from the } \\
\text { antimicrobial results of the } \\
\text { final formulations. } \\
\text { DMSO as the cosolvent for EO } \\
\text { and carbopol } 934(1 \%), \text { HPMC } \\
(5 \%) \text { as gelling agent showed } \\
\text { the best results in the final } \\
\text { formulations. }\end{array}$ & $\begin{array}{l}\text { - The gel showed promising antifungal } \\
\text { activity against other strains used in } \\
\text { this study. The gel was stable at room } \\
\text { temperature. }\end{array}$ \\
\hline
\end{tabular}


Table 1. Cont.

\begin{tabular}{|c|c|c|c|c|c|c|c|}
\hline No. & Techniques & Reference & $\begin{array}{l}\text { Type of Skin Infections/ } \\
\text { Fungi Species }\end{array}$ & Essential Oils & Methods & Findings & Conclusion \\
\hline 30. & & [86] & $\begin{array}{c}\text { Candidiasis (C. krusei } \\
\text { ATCC 6528, C. parapsilosis } \\
\text { ATCC 22019, C. krusei, C. } \\
\text { parapsilosis, C. albicans, C. } \\
\text { glabrata, C. tropicalis }\end{array}$ & Bidens tripartita & $\begin{array}{l}\text { - } \quad \text { EO analysis by GC and } \\
\text { GC-MS techniques. } \\
\text { A hydrogel, bigel and } \\
\text { oleogel were prepared } \\
\text { using an RZR } 2020 \\
\text { mechanical stirrer } \\
\text { The antifungal properties of } \\
\text { B. tripartita EO were also } \\
\text { tested against Candida } \\
\text { species using the modified } \\
\text { agar-well diffusion method. }\end{array}$ & $\begin{array}{l}\text { - The therapeutic efficacy of the } \\
\text { topical formulations is } \\
\text { influenced by active } \\
\text { phytoconstituents and vehicle } \\
\text { characteristics. } \\
\text { The highest activity was } \\
\text { observed against C. tropicalis } \\
\text { and C. krusei (3.7 mm } \\
\text { difference, compared to } \\
\text { hydrogel without BTEO). } \\
\text { The main components were } \\
\text { p-cymen }(4.82 \%), \beta \text {-linalool } \\
(2.85 \%) \text {. }\end{array}$ & $\begin{array}{l}\text { Among the tested gel formulations } \\
\text { combined with BTEO, the } \\
\text { hydrogel-based formulation appeared } \\
\text { to be the optimal combination, } \\
\text { exhibiting antifungal activity against all } \\
\text { tested Candida strains. This oil } \\
\text { appeared to be a promising topical } \\
\text { anticandidal agent. }\end{array}$ \\
\hline 31. & & [87] & $\begin{array}{l}\text { Candidiasis (C. albicans } \\
\text { ATCC 10231, C. krusei } \\
\text { ATCC 6258 and C. } \\
\text { parapsilosis ATCC 90098) }\end{array}$ & $\begin{array}{l}\text { Mediterranean EOs } \\
\text { (Rosmarinus officinalis, } \\
\text { Lavandula x intermedia } \\
\text { “Sumian", Origanum vulgare } \\
\text { subsp. hirtum) }\end{array}$ & $\begin{array}{l}\text { The antifungal } \\
\text { susceptibility test for the } \\
\text { selected (clotrimazole- } \\
\text { nanostructured lipid } \\
\text { carriers) CLZ-NLC } \\
\text { formulations was } \\
\text { performed based on the } \\
\text { broth microdilution method } \\
\text { for yeasts, with minor } \\
\text { adaptations. } \\
\text { For comparative purposes, } \\
\text { in addition to the } \\
\text { CLZ-LNLC (Lavandula) and } \\
\text { CLZ-RNLC (Rosmarinus) } \\
\text { formulations, LNLC and } \\
\text { RNLC systems were also } \\
\text { tested, as well as free EOs } \\
\text { (L and R) and free CLZ. } \\
\text { The cytotoxicity of all } \\
\text { samples (pure EOs and } \\
\text { NLC systems) was } \\
\text { evaluated through the } \\
\text { Alamar Blue }{ }^{\circledast} \text { method. }\end{array}$ & $\begin{array}{l}\text { Results of the in vitro } \\
\text { bisafety on HaCaT (normal } \\
\text { cell line) and A431 (tumoral } \\
\text { cell line) allowed us to select } \\
\text { Lavandula and Rosmarinus as } \\
\text { antiproliferative agents with } \\
\text { the potential for use as } \\
\text { coadjuvants in the treatment } \\
\text { of nontumoral proliferative } \\
\text { dermal diseases } \\
\text { Nanoparticles provided } \\
\text { prolonged in vitro release of } \\
\text { clotrimazole. In vitro studies } \\
\text { against C. albicans, C. krusei } \\
\text { and C. parapsilosis, showed an } \\
\text { increase of the antifungal } \\
\text { activity of } \\
\text { clotrimazole-loaded } \\
\text { nanoparticles prepared with } \\
\text { Lavandula or Rosmarinus, thus } \\
\text { confirming that } \\
\text { NLC-containing } \\
\text { Mediterranean EOs represent } \\
\text { a promising strategy to } \\
\text { improve drug effectiveness } \\
\text { against topical candidiasis. }\end{array}$ & $\begin{array}{l}\text { Taken together, the results of this study } \\
\text { imply that the nanoencapsulation of } \\
\text { the selected antifungal drug into NLC } \\
\text { systems prepared using Mediterranean } \\
\text { EOs as intrinsic oily components is a } \\
\text { promising strategy to improve CLZ } \\
\text { effectiveness against candidiasis. In } \\
\text { particular, the results open the debate } \\
\text { concerning the possible application of } \\
\text { the properties of Lavandula and } \\
\text { Rosmarinus, whose synergistic effects } \\
\text { must be further investigated; this could } \\
\text { bring about a strategy for the use of } \\
\text { CLZ-EO-NLC to overcome the drug } \\
\text { resistance mechanisms associated with } \\
\text { the treatment of topical infections. }\end{array}$ \\
\hline
\end{tabular}


Table 1. Cont.

\begin{tabular}{|c|c|c|c|c|c|c|c|}
\hline No. & Techniques & Reference & $\begin{array}{l}\text { Type of Skin Infections/ } \\
\text { Fungi Species }\end{array}$ & Essential Oils & Methods & Findings & Conclusion \\
\hline 32. & $\begin{array}{l}\text { In vitro-Nonconventional } \\
\text { technology }\end{array}$ & [88] & $\begin{array}{l}\text { Skin infections due to } \\
\text { pathogenic fungi( }(C . \\
\text { albicans, C. tropicalis and } T \text {. } \\
\text { mentagrophytes })\end{array}$ & $\begin{array}{l}\text { Black pepper, Cardamom, } \\
\text { Cumin, Boswellia and } \\
\text { Patcholi }\end{array}$ & $\begin{array}{l}\text { - Antifungal activity by agar } \\
\text { well diffusion method. } \\
\text { For synergistic activity } \\
\text { between Fluconazole and } \\
\text { EO, sterile strips of } 5 \mathrm{~cm} \times \\
1 \mathrm{~cm} \text { were used. }\end{array}$ & $\begin{array}{l}\text { The results indicated that all } \\
\text { the oils inhibited fungal } \\
\text { strains in varying degrees of } \\
\text { dilutions. } \\
\text { Boswellia EO was found to be } \\
\text { the most effective in terms of } \\
\text { antifungal activity against } C \text {. } \\
\text { tropicalis and Cardamom EO } \\
\text { against } T \text {. mentagrophytes. } \\
\text { The results indicated that } \\
\text { Boswellia EO and Fluconazole } \\
\text { in combination acted as the } \\
\text { most powerful antifungal } \\
\text { agent against } C \text {. tropicalis, } \\
\text { even at } 1: 10 \text { dilution and } \\
100 \mu \mathrm{g} / \mathrm{mL} \text {, respectively. }\end{array}$ & $\begin{array}{l}\text { These results indicated that the active } \\
\text { components present in EOs should be a } \\
\text { focus area of future in vivo research, } \\
\text { especially in conjunction with existing } \\
\text { antifungal drugs. The molecular } \\
\text { mechanisms, mode of action, stability, } \\
\text { toxicity, and efficacy of the active } \\
\text { components isolated from EOs need to } \\
\text { be further studied and evaluated. }\end{array}$ \\
\hline 33. & $\begin{array}{l}\text { In vitro and } \\
\text { In vivo-Conventional } \\
\text { technology }\end{array}$ & [89] & $\begin{array}{l}\text { Body aches and dermatitis } \\
\text { (A. flavus, A. niger, F. solani, } \\
\text { Mucor piriformis, } \\
\text { Wickerhamomyces anomalus, } \\
\text { Wickerhamomyces anomalus, } \\
\text { Deboromyces hansenii, and } \\
\text { C. albicans) }\end{array}$ & Parrotiopsis jacquemontiana & $\begin{array}{l}\text { Phytochemical } \\
\text { characterization of oil was } \\
\text { determined using GC-MS } \\
\text { and Fourier Transformed- } \\
\text { Infrared spectroscopy } \\
\text { (FT-IR). } \\
\text { The antimicrobial potential } \\
\text { of oil wasinvestigated by } \\
\text { disc diffusion method. } \\
\text { Wound healing was } \\
\text { performed in vivo with } \\
\text { determination of wound } \\
\text { contraction rates, } \\
\text { histopathology, hemostatic } \\
\text { potential and } \\
\text { hydroxyproline estimation. }\end{array}$ & 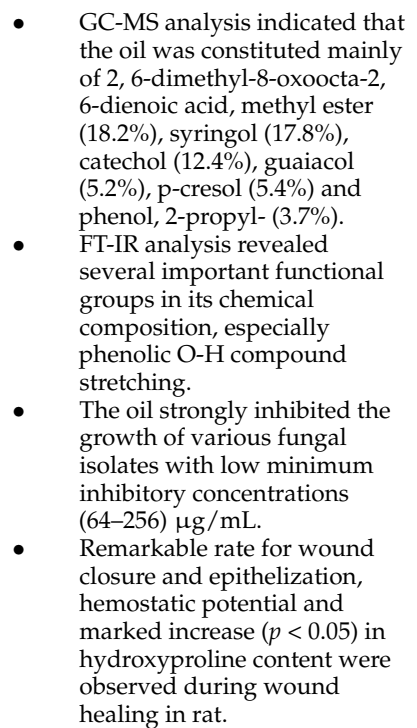 & $\begin{array}{l}\text { The results suggested that oil can be } \\
\text { used as a potential source of wound } \\
\text { healing therapeutics. }\end{array}$ \\
\hline
\end{tabular}


Table 1. Cont.

No. Techniques

Reference Type of Skin
Fungi Species

Skin infections

34. In vitro and In vivo - Conventional technology
[90]
(Chrysosporium tropicum
Trichophyton simii, $T$.

rubrum and Chrysosporium

$$
\text { indicum) }
$$

Methods

Essential Oils

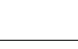

EO analysis by GC-MS. Antidermatophytic activity was determined by disc diffusion method and minimum inhibitory

- Acute dermal irritation assay was applied for albino mice.
Findings

- Thymol was found to be the major compound (58.88\%), followed by p-cymene $(24.02 \%), \gamma$-terpinene $(13.77 \%)$

- Maximum zone of inhibition was observed against $C$. tropicum $(63.83+/-0.166$ $\mathrm{mm}$ ) followed by T. simii (57 $(51.33+/-0.333 \mathrm{~mm})$ and $C$. indicum $(45+/-0.577 \mathrm{~mm})$.

- Five fractions were separated under different temperature conditions, labelled as TA(I)-TA(V). Maximum effects were seen in case of
$\mathrm{TA}(\mathrm{IV})$ and $\mathrm{TA}(\mathrm{V})$ fractions

- Excellent results of TA(V) were observed against $M$. gypseum $(0.015+/-0.002 \mathrm{mu}$ $1 / \mathrm{mL})$, followed by $M$. canis rubrum $(0.02+/-0.000 \mathrm{mu}$, $1 / \mathrm{mL})$ and $C$ albicans $(0.05$ $+/-0.003 \mathrm{mu} \mathrm{l} / \mathrm{mL}$ ).

- Low concentrations, i.e., up to $3 \%$, did not show any irritation on mice skin. At $5 \%$ three mice showed mild erythema, while at $7 \%$ concentration, all five mice exhibited well-defined

Conclusion

- This study concluded that the EO of $T$. ammi and its fractions have strong antidermatophytic properties with no side effect at low concentrations, and 
Table 1. Cont.

No. Techniques
Skin disease due to fung

strains(C. albicans, C. strains(C. albicans, $C$.
parapsilosis, C. tropicalis; $A$. niger, A. terreus, A. flavus, A. fumigatus, Penicillium sp.
Lemon grass (Cymbopogon citratus (DC.) Stapf) and Mucor sp.
Methods

Essential Oils

Findings

Conclusion

- The major components were
geranial $(42.2 \%)$, neral $(31.5 \%)$

and $\beta$-myrcene $(7.5 \%)$.

- LGEO exhibited promising

antifungal effects against $C$.

albicans, C. tropicalis, and $A$.

niger, with different inhibition

zone diameters (IZDs) (35-90

increasing oil volume.

- Higher anti-Candida activity

was observed in the vapor

phase.

- $\quad$ LGEO chemical profiling by

In an evaluation of the

anti-inflammatory effect,

LGEO $(10 \mathrm{mg} / \mathrm{kg}$,

Antifungal activity using disc diffusion and vapo

- The anti-inflammatory

potential of LGEO was

assessed by the

carrageenan-induced paw edema test.

- $\quad$ Topical anti-inflammatory activity was evaluated as inhibition of croton oil-induced ear edema in

- The resulting inflammatory reaction was also evaluated roscopic inspection. shown to significantly reduce administered orally) was carrageenan-induced paw edema, with a similar effect that of oral diclofenac (50 $\mathrm{mg} / \mathrm{kg}$ ), which was used as administration of $\mathrm{LGEO}$ showed dose-dependent anti-inflammatory activity. In addition, topical application of LGEO in vivo indicated a potent

anti-inflammatory effect, as demonstrated by the use of a mouse model of croton oil-induced ear edema. To ou knowledge, this is the first such report to be published The topical application of LL/ear significantly reduced acute ear edema induced by croton oil in 62.5 and $75 \%$ of

mice, respectively.
In addition, histological analysis clearly confirmed that LGEO inhibits the skin inflammatory response in
The results of this present study ndicated that LGEO has potential in the development of drugs for the treatment of fungal infections and skin inflammation that should be explored in future studies. 
Table 1. Cont.

\begin{tabular}{|c|c|c|c|c|c|c|c|}
\hline No. & Techniques & Reference & $\begin{array}{l}\text { Type of Skin } \\
\text { Infections/ } \\
\text { Fungi Species }\end{array}$ & Essential Oils & Methods & Findings & Conclusion \\
\hline 36. & $\begin{array}{c}\text { In vitro and } \\
\text { In vivo-Conventional } \\
\text { technology }\end{array}$ & [92] & $\begin{array}{l}\text { Skin infections } \\
\text { (M. gypseum and T. } \\
\text { mentagrophytes) }\end{array}$ & $\begin{array}{c}\text { Ageratum houstonianum } \\
\text { Mill., }\end{array}$ & $\begin{array}{l}\text { The proportions of } \\
\text { EO/griseofulvin tested } \\
\text { were 8:2 and 10:1 }(w / w) \text {. } \\
\text { The acute dermal } \\
\text { toxicity of this oil was } \\
\text { evaluated on } \\
\text { guinea-pigs (Cavia } \\
\text { porcellus) using a } \\
\text { standard method. } \\
\text { Agar dilution method } \\
\text { with serial dilution of } \\
\text { the oil and the mixtures } \\
\text { was used for } \\
\text { antidermatophytic tests. }\end{array}$ & $\begin{array}{l}\text { - } \quad \text { The MIC of the EO was } 80 \\
\mu \mathrm{g} / \mathrm{mL} \text { for the tested } \\
\text { dermatophytes. } \\
\text { The } 8: 2 \text { mixture was } 20 \\
\mu \mathrm{g} / \mathrm{mL} \text {, whereas those of } \\
\text { the } 10: 1 \text { mixture were } 8 \\
\text { and } 10 \text { ug mL for } M \text {. } \\
\text { gypseum and } T \text {. } \\
\text { mentagrophytes, } \\
\text { respectively. } \\
\text { Compared to the control } \\
\text { group, we noted no } \\
\text { diarrhoea, nor any change } \\
\text { in treated skin or fur } \\
\text { appearance. In contrast, } \\
\text { the degree of sensitivity to } \\
\text { noise, reaction to pinch, } \\
\text { activity (locomotion) and } \\
\text { reactivity decreased with } \\
\text { increases in the dose. The } \\
\text { LD50 was determined to } \\
\text { be } 5 \mathrm{~g} / \mathrm{kg} \text { b.wt. }\end{array}$ & $\begin{array}{l}\text { These data suggest that the EO of } \\
\text { the leaves of } A \text {. houstonianum } \\
\text { contains antidermatophytic } \\
\text { compounds, and may not be toxic } \\
\text { when used topically. A } \\
\text { potentialization effect was } \\
\text { observed between the EO and } \\
\text { griseofulvin. }\end{array}$ \\
\hline
\end{tabular}


Table 1. Cont.

No. Techniques

Reference

Type of Skin Infections/

Fungi Species

Essential Oils

Methods

- $\quad$ MIC and MFC of LGO were determined using the broth
macrodilution method.

LGO-loaded nanosponge

were prepared using the

emulsion solvent

- $\quad$ Thaporation method.
$\quad$ irritation effect of the chosen gel formulation, $\mathrm{F}$ out a Draize patch test on six albino rats. The animals' backs were shaved $24 \mathrm{~h}$ before the application of the formulation, and then $0.5 \mathrm{~g}$ gel was spread uniformly on the hair-free skin with an area of $4 \mathrm{~cm}^{2}$. The skin was observed for any visible changes after 24,48 and $72 \mathrm{~h}$ from the formulation.

37. In vitro and technology

[93]

strain ATC 100231)

Lemongrass oil (LGO) is a

- $\quad$ Male albino

Male albino rats weighing $150-180 \mathrm{~g}$ were housed in
individual cages and given individual cages and given libitum. Animals were subjected to intraperitoneal injection of

cyclophosphamide (100 $\mathrm{mg} / \mathrm{kg}$, body weight) for three days before fungal infection to suppress their immunity, with the aim of cutaneous infection.

- C. albicans, ATCC 10231 was

Findings

Conclusion

- $\quad$ The minimal inhibitory concentration and minima fungicidal concentration of LGO against $C$. albica ATC 100231, determined using the broth macrodilution method were found to be 2 and $8 \mu \mathrm{L} / \mathrm{mL}$, respectively.

- The selected formulation, F9, was tested for skin irritation and antifungalactivity against C. albicans; the results and effective antifungal activity of the prepared hydrogel.
LGO was successfully incorporated into an EC nanosponge using the emulsion solvent evaporation method, followed by integration into a carbopol hydrogel. Among the nine prepared hydrogels integrating

lemongrass-loaded nanosponges, the F9 formulation was chosen for further study on the basis of its particle size and controlled release profile. The selected formula showed no skin irritation and in vivo antifungal activity in male albino rats. These results are prolication of the incorporation of LCO in pharmaceutical formulations with the benefit of decreasing the hazards of its use in folk medicine in crude form. 
Table 1. Cont.

\begin{tabular}{|c|c|c|c|c|c|c|c|}
\hline No. & Techniques & Reference & $\begin{array}{l}\text { Type of Skin } \\
\text { Infections/ } \\
\text { Fungi Species }\end{array}$ & Essential Oils & Methods & Findings & Conclusion \\
\hline 38. & $\begin{array}{l}\text { In vitro and In vivo- } \\
\text { Nonconventional } \\
\text { technology }\end{array}$ & [94] & $\begin{array}{l}\text { Skin infections ( } T \text {. } \\
\text { mentagrophytes, } T \text {. } \\
\text { rubrum, T. verrucosum } \\
\text { and M. canis) }\end{array}$ & Cymbopogon martini & $\begin{array}{l}\text { Hydrodistillation aerial } \\
\text { part C. martini and } \\
\text { topical formulations } \\
\text { were prepared in five } \\
\text { different semisolid } \\
\text { bases. } \\
\text { In vitro antimicrobial } \\
\text { investigations were } \\
\text { performed on EO and } \\
\text { topical formulations. } \\
\text { Skin sensitizations of the } \\
\text { formulations were } \\
\text { evaluated using guinea } \\
\text { pig maximization- }\end{array}$ & $\begin{array}{l}\text { C. martini EO has shown } \\
\text { broad-spectrum } \\
\text { antimicrobial potency } \\
\text { against all tested } \\
\text { organisms, with MIC } \\
\text { value ranging from } 0.65 \text { to } \\
10 \mu \mathrm{m} / \mathrm{mL} \text {. } \\
\text { Absolute inhibitions of } \\
\text { growth of fungi were } \\
\text { observed against } T \text {. } \\
\text { mentagrophytes and } T \text {. } \\
\text { rubrum at concentrations } \\
\text { above } 1 \% \text { of oil and } \\
\text { against } M \text {. canis and } T \text {. } \\
\text { verrucosum at a } \\
\text { concentration of } 4 \% \text { oil. } \\
\text { Among topical } \\
\text { formulations, the highest } \\
\text { antimicrobial activity was } \\
\text { recorded in hydrophilic } \\
\text { ointment, followed by the } \\
\text { macrogol blend ointment. } \\
\text { The antimicrobial activity } \\
\text { of oil was higher in fungal } \\
\text { pathogens compared to } \\
\text { bacteria. Gram-positive } \\
\text { bacteria were more } \\
\text { sensitive than } \\
\text { gram-negative bacteria. } \\
\text { A hydrophilic and } \\
\text { macrogol blend containing } \\
5 \% \text { oil did not produce any } \\
\text { skin sensitization on } \\
\text { guinea pigs. }\end{array}$ & $\begin{array}{l}\text { Topical formulations of C. martini } \\
\text { EO may be alternative topical } \\
\text { agents with safe broad-spectrum } \\
\text { activity for the treatment of skin } \\
\text { disorders. Further studies should } \\
\text { focus on shelf-life and clinical } \\
\text { studies of the product. }\end{array}$ \\
\hline
\end{tabular}


Table 1. Cont

\section{No. Techniques}

\section{Reference}

Type of Skin

Infections/

Fungi Species
Dermatophytes and some filamentous fungi (A. flavus, A. niger, A. In vitro and In vivoNonconventional technology
[95] fumigatus, Microspoum

udouni, M. nanum, T.

mentagrophytes, $T$.

verrucosm and $\mathrm{T}$

violaceum)
C. martini and

Chenopodium

ambrosioides
Methods

- Chemical constituents of

EOs were determined by GC-MS.

- The fungitoxicity of EOs and their combination was also evaluated against some filamentous fungi and other species of

dermatophytes by poisoned food technique at concentrations of 200, 600 and $800 \mathrm{ppm}$.

- $\quad$ Male guinea pigs (5-8 months old, 350-400 g) were obtained from Central Animal House Institute of Medical Sciences, BHU, Varanasi.

- The ointment of each EO and their combination were prepared by mixing $1 \mathrm{~mL}$ of the oil with $100 \mathrm{~g}$ petroleum jelly.

- Treatments were started from the sixth day after inoculation and continued until complete recovery was achieved. To the infected area was applied $0.2 \mathrm{~g}$ ointment twice a day in the treatment set. In the control set, only

petroleum jelly without EO was used.
- $\quad$ The major constituents of the essential oil of $C$. martini were trans-geraniol $(60.9 \%)$, $\beta$-elemene $(12.26 \%)$, E-citral (3.95\%) and linalool (3.44\%).

- The minimum inhibitory concentrations of EO and of their combination were found between 150 and $500 \mathrm{ppm}$, while those of known antifungal drug ranged from 1000 to 5500 ppm.

EOs ointments were prepared and applied against induced ringworm in a guinea pig mode. Disease removal was observed in 7-21 days, and the hair samples showed negative results for fungal culture in a time-dependent manner after the application of EO ointments.

\section{Conclusion}

- The results provided scientific validation for the use of these EOs in the treatment of dermatophyte infections; as such, the topical application of these EOs may be recommended as an alternative to synthetic drugs. 
Table 1. Cont.

\begin{tabular}{|c|c|c|c|c|c|c|c|}
\hline No. & Techniques & Reference & $\begin{array}{l}\text { Type of Skin } \\
\text { Infections/ } \\
\text { Fungi Species }\end{array}$ & Essential Oils & Methods & Findings & Conclusion \\
\hline 40. & Clinical Interventions & [96] & $\begin{array}{l}\text { Ringworm (tenia } \\
\text { corporis) ( } M \text {. and } T \text {. } \\
\text { mentagrophytes) }\end{array}$ & Curcuma longa $\mathrm{L}$. & $\begin{array}{l}\text { The oil was formulated } \\
\text { in the form of an } \\
\text { ointment, } 1 \% \mathrm{w} / \mathrm{v} \text { and } \\
\text { subjected to topical } \\
\text { testing on patients of the } \\
\text { Out Patient Department } \\
\text { (OPD) at Moti Lal Nehru } \\
\text { Medical College, } \\
\text { Allahabad. Patients } \\
\text { were selected on the } \\
\text { basis of potassium } \\
\text { hydroxide (KOH) } \\
\text { positive results and } \\
\text { diagnosis of tenia } \\
\text { corporis. }\end{array}$ & $\begin{array}{l}\text { A C. longa leaves EO was } \\
\text { fungicidal at } 2.5 \mu \mathrm{L} / \mathrm{mL} \text {, } \\
\text { at which it was tolerated } \\
\text { in heavy doses. The } \\
\text { fungicidal activity was } \\
\text { thermostable up to } 80^{\circ} \mathrm{C} \\
\text { and a shelf life of up to } \\
24 \text { months was } \\
\text { determined. } \\
\text { The oil also showed a } \\
\text { broad fungitoxic spectrum, } \\
\text { inhibiting the mycelial } \\
\text { growth of other fungi, viz., } \\
\text { E. floccosum, M. nanum, } T \text {. } \\
\text { rubrum, T. violaceum. } \\
\text { Moreover, at up to } 5 \% \\
\text { concentration, it did not } \\
\text { exhibit any adverse effect } \\
\text { on mammalian skins. } \\
\text { After the second week of } \\
\text { treatment, all patients } \\
\text { were KOH-negative. At } \\
\text { the end of medication, } 75 \% \\
\text { of patients recovered } \\
\text { completely, while } 15 \% \\
\text { showed significant } \\
\text { improvement from } \\
\text { the disease. }\end{array}$ & $\begin{array}{l}\text { After ongoing successful clinical } \\
\text { trials, it was concluded that the } \\
\text { ointment could be exploited } \\
\text { commercially. The relationship of } \\
\text { dermatophytes to the toxicity of } \\
\text { the oil, vis-a-vis phylogeny, } \\
\text { evaluated using the molecular data } \\
\text { of the pathogens, was also } \\
\text { discussed. }\end{array}$ \\
\hline
\end{tabular}


Table 1. Cont.

\begin{tabular}{|c|c|c|c|c|c|c|c|}
\hline No. & Techniques & Reference & $\begin{array}{l}\text { Type of Skin } \\
\text { Infections/ } \\
\text { Fungi Species }\end{array}$ & Essential Oils & Methods & Findings & Conclusion \\
\hline 41. & & [97] & $\begin{array}{c}\text { Pityriasis versicolor } \\
\text { (Malassezia sp.) }\end{array}$ & Myrtus communis & $\begin{array}{l}\text { - Forty one patients with } \\
\text { PV that had not received } \\
\text { any treatment for PV } \\
\text { two weeks prior to } \\
\text { enrollment. } \\
\text { Samples were taken } \\
\text { from four different } \\
\text { locations: the surface } \\
\text { layers of the back, } \\
\text { thorax, arms and facial } \\
\text { skin (area of } 4 \mathrm{~cm}^{2} \text { ), } \\
\text { using adhesive tape. } \\
\text { Chemical profiling via } \\
\text { LC-MS/MS. } \\
\text { Antifungal effect of EO } \\
\text { on Malassezia strains } \\
\text { was tested using } \\
\text { European committee on } \\
\text { antimicrobial } \\
\text { susceptibility testing } \\
\text { (EUCAST) broth } \\
\text { microdilution method. }\end{array}$ & 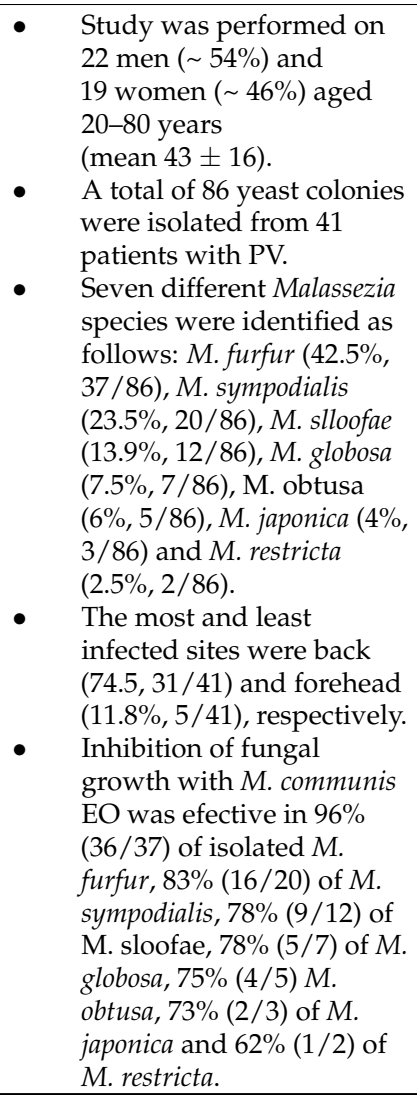 & $\begin{array}{l}\text { The broad-spectrum antimicrobial } \\
\text { activities of M. communis EO and } \\
\text { its potent inhibiting activity on } \\
\text { Malassezia growth deserve further } \\
\text { research, with the aim of } \\
\text { potentially applying this EO in the } \\
\text { topical treatment of skin diseases }\end{array}$ \\
\hline
\end{tabular}




\section{Discussion}

In general, body aches are recognized and accepted as an initial symptom that could signify various underlying ailments. Dermatitis is normally acknowledged as a common condition of skin irritation that manifests in the form of dry skin or rashes. It usually instigates itchiness and may also cause blisters or skin flaking. Common conditions include atopic dermatitis (eczema), seborrheic dermatitis (dandruff) and contact dermatitis [98,99]. Acne is another inflammatory condition widely known to affect teenagers. Although this is usually considered a common ailment, certain severe forms can result in scarring, that may affect self-esteem and social interaction, along with causing psychological distress [100].

Infections are typically defined as the acquisition of a microbe by a host, which results when the microorganism is not eradicated from the host upon direct contact, thus initiating disease [101,102]. It has been observed that fungal infections are becoming more prominent; this could be explained by the sharp growth of high-risk populations and the application of treatment modes that allow for improved survival rate [103]. Several variations of endemic fungal infections have been observed with specific geographical distribution due to climate change, human habitats expansion, ease of travel and population migrations [1]. There are four key prerequisite criteria for fungi to infect humans: its ability to colonize or penetrate surface barriers, its ability to absorb nutrients via lysis and absorption of human tissue, its ability to counteract innate and adaptive immunity associated pressure, and its ability to grow at typical human body temperature [104].

The current practice in the treatment of fungal infections is solely focused on the application of traditional antifungal agents. However, as new species of fungi emerge, different approaches are necessary, given the increased resistance toward commonly available antifungal medications. Based on extensive research performed on EOs, the potential of these oils for antifungal based therapies has gained huge attention in recent years. Our review highlights numerous studies that have evaluated the potential of various types of EOs against human pathogenic fungi that were examined via in vitro, in vivo as well as clinical research. The listed research articles were also defined and classified as conventional and nonconventional, where applicable.

\subsection{EOs in Conventional Approaches}

Among the in vitro studies, Candida spp. infections were among the most common. The hypothesis of the previous study was that the spread of candida infections could be avoided in the occurrence of a healthy immune system, except when scrapes or cuts are found on the body [105]. Numerous EOs were shown to be suitable to control candida infections. Commercially available lemon EOs have gained attention and also been shown to possess antifungal potential against three Candida species (C. albicans, C. tropicalis and C. glabrata), where the growth of $C$. albicans specifically was inhibited across the full spectrum of concentrations used [79]. In another study, anticandidal activities were examined against C. torulopsis, C. stellatoidea and C. albicans using Physalis angulata EO. P. angulata is an annual herbaceous plant in the Solanaceae family which is recognized for its medicinal value. $P$. angulata EO demonstrated excellent characteristics as an antifungal agent against all three candida strains that are usually resistant to antibiotics. As such, additional research on its anti-infective properties is warranted [72].

Cabral and colleagues evaluated the antifungal potential of Juniperus communis subsp. alpina (Suter) Celak needles EO [75]. J. communis L. is an evergreen shrub or tree with fleshy female cones, where the cone scales resemble berries; it occurs throughout Europe, Asia and North America [106]. The evaluation of juniper needle oil revealed excellent activity, in particular to M. canis and T. rubrum, with MIC and minimum lethal concentrations (MLC) of $0.32 \mu \mathrm{L} / \mathrm{mL}$ [75]. The oil was made up largely of monoterpene hydrocarbons $(78.4 \%)$, with the main components being sabinene $(26.2 \%), \alpha$-pinene $(12.9 \%)$ and limonene $(10.4 \%)$. Cell viability studies indicated the superiority of needle oil with no cytotoxic effects observed in HaCat keratinocytes when tested at 0.32 and $0.64 \mu \mathrm{L} / \mathrm{mL}$, compared to a previous study on berry EO [75]. 
Another study investigated the effect of two EOs (E. caryophylla and M. sp cf piperita) on six human pathogenic fungi (four filamentous fungi (dermatophytes): T. rubrum (1 and 2), T. violaceum, and T. soudanense) and two pathogenic yeasts (C. albicans 1 and 2). Mentha sp cf piperita is a herbal plant belonging to the Lamiaceae family, native to temperate regions, with a fresh, sweet smell that is traditionally applied in the treatment of gastritis, muscular pains or toothache [107]. E. caryophylla (Myrtaceae) (clove) is a tree of 10-12 $\mathrm{m}$ in height that originates from Indonesia but which is also harvested in African countries. It is widely used as a spice, as well as for the treatment of toothache and in infection remedies [108]. The study showed that Mentha sp cf piperita EO presented weak activity, with MIC of $2.5 \mu \mathrm{L} / \mathrm{mL}$ against Tricophyton strains, while no activity was shown with C. albicans [74]. Additionally, E. caryophylla EO exhibited the highest activity, with MIC and MFC of $0.25 \mu \mathrm{L} / \mathrm{mL}$ and $0.125 \mu \mathrm{L} / \mathrm{mL}$ for filamentous fungi and MIC of $0.5 \mu \mathrm{L} / \mathrm{mL}$ for both yeast strains, while the MFC value was $1 \mu \mathrm{L} / \mathrm{mL}$ for one yeast strain and was not determined for the second [74].

In a study by Valente et al. [65], the potential of D. carota subsp. gummifer EO as an antifungal and anti-inflammatory was evaluated against multiple collections and clinical strains via macrodilution broth assays. Among the tested strains were two Candida strains isolated from recurrent cases of vulvovaginal candidosis (C. krusei $\mathrm{H} 9$ and C. guillermondii MAT 23), three type strains from the American Type Culture Collection (C. albicans ATCC 10231, C. tropicalis ATCC 13803, C. parapsilosis ATCC 90018), one type strain from the Colección Española de Cultivos Tipo (C. neoformans CECT 1078), three dermatophyte strains isolated from nails and skin (T. mentagrophytes FF7, M. canis FF1, E. floccosum FF9), two type strains from CECT (T. rubrum CECT 2794, M. gypseum CECT 2908), one Aspergillus strain isolated from bronchial secretions (A. flavus F44) and two type strains from ATCC (A. niger ATCC 16404 and A. fumigatus ATCC 46645). Chemical characterization of the oil revealed high amounts of monoterpenes with geranyl acetate and $\alpha$-pinene as the major components. This EO action was shown to be active against dermatophytes and C. neoformans (MIC range: $0.32-0.64 \mu \mathrm{L} / \mathrm{mL}$ ). The promising results shown by this EO led to the recommendation of future studies with a specific emphasis on peripheral and central nervous systems (CNS), implying the need for in vivo research focused in dermatophytosis and inflammatory disease management [65].

Two more genera of fungi are commonly related to skin diseases: Microsporum and Trichophyton. These opportunistic filamentous fungi belong to dermatophytes [109]. From our review, we found that many studies have been done to find methods to counter these two species. Artemisia is one of the most widely distributed species of the Asteraceae family, and is well-known for its pharmacological benefits. A. sieberi was tested on dermatophytes against several strains (T. rubrum, T. mentagrophytes, M. canis, M. gypseum, T. schoenleinii and T. verrucosum var. album), revealing higher sensitivity of M. gypseum, T. rubrum and M. canis and suggesting its suitability as a topical antifungal agent. However, this study indicated that collection site and harvest time affect the yield and chemical composition of the EO, although no significant differences were observed with respect to its antidermatophyte activities [59].

Rezgui and colleagues studied the effects of $M$. vulgare EO, extract and its active compound (marrubiin), and observed approximately $50 \%$ inhibition for T. mentagrophytes and E. floccosum with respect to marrubiin tested at $100 \mathrm{mg} / \mathrm{mL}$. Antiphytopathogenic activity was also conducted, with only marrubiin being found to be active against $B$. cinerea at the highest dose $(32.40 \%)$. The authors concluded that $M$. vulgare and marrubiin could be used as natural antifungal agents for skin dermatophyte infections [73]. Myristica fragrans is an edible plant that grows in the evergreen forests of West Africa. The seeds have both economic and medicinal value, especially for the local community. Inhibition was observed against several pathogenic fungi, e.g., C. tropicalis $(1.3 \mathrm{~cm})$, C. albicans $(0.8 \mathrm{~cm}), R$. miehei $(0.6 \mathrm{~cm})$ and $C$. glabrata $(0.6 \mathrm{~cm})$ with $M$. fragrans $\mathrm{EO}$, although no inhibition was reported with $A$. niger and $A$. fumigates [61].

In Lebanon, Lamiaceae species such as C. capitatus L., L. stoechas L., L. angustifolia Mill., M. spicata L. subsp. condensata, O. syriacum L., R. officinalis, S. fruticosa Miller., S. cuneifolia 
Ten., S. thymbra L., T. spicata L., and V. agnus-castus L. are quite popular due to their use as a food, a condiment or as traditional medicine in the treatment gastrointestinal disorders and microbial infections. The EOs of Lamiaceae sp. was shown to be efficient, especially toward T. rubrum and C. albicans, that reported MIC values ranging between $64-128 \mu \mathrm{g} / \mathrm{mL}$; this was attributed to the presence of large amounts of thymol and carvacrol components [60]. A recent review by Karpinski highlighted the antifungal properties of EOs from 72 Lamiaceae plants. Linalool, $\beta$-caryophyllene, limonene, $\beta$-pinene, 1,8 -cineole, carvacrol, $\alpha$-pinene, $p$ cymene, $\gamma$-terpinene, and thymol were identified as the major components among the tested plants; these compounds are known to possess antifungal characteristics. On the whole, the review concluded that more than half of these EOs presented MIC activity $(<1000 \mu \mathrm{g} / \mathrm{mL})$, with Clinopodium, Lavandula, Mentha, Thymbra and Thymus EOs displaying the best activities [110].

In addition to the species mentioned above, Lebanon is also well-known for EOs from conifer plants such as A. cilicica, C. sempervirens, J. excelsa, J. oxycedrus, C. libani and C. macrocarpa gold crest. The efficacy of such oils was evaluated against C. albicans and several isolates of Trichophyton spp. Based on the results, the highest sensitivity was observed with Trichophyton spp. to all tested EOs (MIC: $32-512 \mu \mathrm{g} / \mathrm{mL}$ ). This study, however, highlighted interesting activity of a C. macrocarpa $\mathrm{EO}$ on dermatophytes (MIC: 32-64 $\mu \mathrm{g} / \mathrm{mL}$ ), whereby each major component, as well as an artificial EO, were tested on T. rubrum, suggesting a possible contribution of a minor component to the overall observed activity. The findings strengthen the potential of EOs of Lebanese conifers for use in antimicrobial preparations for the treatment of superficial infections [67].

In another test against T. rubrum and T. mentagrophytes, the antifungal activities of A. betulina and C. album EOs was evaluated using electron microscopy based on the mechanism of action. It was found that fungal growth was inhibited on all plates exposed to the EOs volatiles with different inhibition rates observed among the various fungal species, EOs and tested volumes. The highest inhibition was recorded on T. rubrum at $40 \mu \mathrm{L}$ via the action of $A$. betulina EO, with a fungal growth index (FGI) of $2.3 \%$ indicating its capacity as a strong antifungicidal agent. The hyphae and spores of T. rubrum were also destroyed due to the volatile effects. The major components identified in A. betulina EO are limonene $(29.8 \%)$, menthone $(21.6 \%)$, and isomenthone $(14.7 \%)$, while pinene $(27.4 \%)$ and myrcene $(14.5 \%)$ makes up the major part of C. album [69]. In the formulation of skincare products, the C. album (Thunb) Bart. \& H. L. Wendl (Rutaceae) has been used by the Khoisan people by rubbing it on their skin. However, it is less popular in South Africa as a traditional medicine. The mechanism of action of $A$. betulina EO volatiles was shown to be through spore growth inhibition as well as production and morphology alteration via destruction of hyphae and spores. Overall, this research gave remarkable insights into the possible use of $A$. betulina as an antifungal agent [70].

Another study on the potential of EOs from L. luisieri and C. citratus against T. rubrum and T. mentagrophytes was conducted, whereby strong antifungal activity was observed with most clinical strains. Positive interaction between L. luisieri EO combined with terbinafine was observed against terbinafine-resistant strain (Tr ATCC MYA-4438). Significant reduction of the germination was observed above $100 \mu \mathrm{g} / \mathrm{mL}$. Both oils were found to be safe to macrophage mammalian cells at the tested concentrations. This study describes the antifungal activity of L. luisieri and C. citratus EOs against dermatophytes, which could be useful in the design of new formulations of topical treatments [77].

Since ancient times, several Thymus species have been used in traditional medicine to combat pathogenic microorganisms. In a study by Goncalves et al. [63], chemical profiling and antifungal activity of four types of oils from Thymus zygis subsp. sylvestris were evaluated against yeasts, dermatophyte and Aspergillus strains. Carvacrol (25.0\%), thymol $(23.8 \%)$, geranyl acetate $(20.8 \%)$, geraniol $(19.8 \%)$ and linalool $(30.0 \%)$ were the major identified components. MTT (3-(4,5-dimethylthiazol-2-yl)-2,5-diphenyltetrazolium bromide) assay revealed that the oil composed of high carvacrol concentrations presented stronger antifungal activities against dermatophytes, with no cytotoxic effect at $0.08-0.16 \mu \mathrm{L} / \mathrm{mL}$, 
for up to $24 \mathrm{~h}$. A lack of cytotoxicity was also observed with this oil in mouse skin dendritic cells at concentrations where significant antifungal activity was obtained $(0.16 \mu \mathrm{L} / \mathrm{mL})$. Based on these findings, it was proposed that T. zygis EO is highly capable as an antifungal agent with minimal detrimental effects, and that it should be explored in more detail [63].

In combatting ringworm infections, S. khuzistanica $\mathrm{EO}$, ethanol and aqueous extract were tested for their antifungal activity. In the study, the antifungal activities of S. khuzistanica EO (MIC: $40-190 \mu \mathrm{g} / \mathrm{mL}$ ) were found to be higher than its ethanol extract (MIC: 40-770 $\mathrm{gg} / \mathrm{mL}$ ), while $S$. khuzistanica aqueous extract had no antifungal activity against dermatophytes (MIC: $1550-3100 \mu \mathrm{g} / \mathrm{mL}$ ). This study noted the potential of S. khuzistanica $\mathrm{EO}$ as a topical therapy in the treatment of skin fungal infections. It also noted that both S. khuzistanica EO and its ethanol extract could be further explored for their antifungal activities [64].

S. officinalis L. belongs to the Lamiaceae family; it was evaluated for its antifungal and anti-inflammatory activity. S. officinalis EO indicated antifungal activities against dermatophytes and significantly inhibited nitric oxide (NO) production stimulated by lipopolysaccharide (LPS) in macrophages without affecting cell viability in concentrations up to $0.64 \mu \mathrm{L} / \mathrm{mL}$. This study claimed to be the first report on the in vitro anti-inflammatory potential of S. officinalis oil; the authors demonstrated that the bioactive concentrations of S. officinalis oils did not affect the mammalian macrophages and keratinocytes, making them suitable for use in skin care formulation for cosmetic and pharmaceuticals applications [66].

The antifungal activity of $D$. tenuifolium $\mathrm{EO}$ was evaluated against yeast, dermatophyte and Aspergillus strains. The oils revealed significant antifungal activity against C. neoformans and dermatophyte strains, and significantly inhibited NO production stimulated by LPS in macrophages, without affecting cell viability at concentrations ranging from $0.64-1.25 \mathrm{~L} / \mathrm{mL}$. A chemical analysis found that the oil was mostly composed of monoterpene hydrocarbons with myrcene as the major component. This research provided significant information about the pharmacological activities of $D$. tenuifolium EO which is relevant to its use as an antifungal and anti-inflammatory agent for treatment of contact dermatitis, skin infections as well as its role as an anti-inflammatory agent. Thus, it was proposed that its beneficial effects and usage for the prevention of diseases related to fungal and inflammation need to be further examined [68].

In a screening of $C$. lemon and $C$. sinensis oils by disc diffusion method in combatting M. furfur, the diameter of the inhibition zone was found to be 50 and $20 \mathrm{~mm}$, i.e., greater than those of reference antibiotics, gentamycin and streptomycin, at 16.5 and $17 \mathrm{~mm}$, respectively. MIC of both lemon and orange oil against $M$. furfur was found to be 0.8 and $2.2 \mu \mathrm{L} / \mathrm{mL}$. These findings support the use of $C$. lemon and C. sinensis oil as a traditional herbal medicine for the treatment of $P$. versicolor infection of the skin [82]. The evaluation of Bursera morelensis EO indicated inhibition of all the filamentous fungi. F. monilifome (IC50: $2.27 \mathrm{mg} / \mathrm{mL}$ ) was the most sensitive fungal strain. This work provided scientific evidence for the antimicrobial activity of the B. morelensis [71].

In addition to in vitro approaches, several investigations were also conducted with in vivo models combined with in vitro approaches. Among the most widely covered EOs in this review for combined approaches were P. jacquemontiana, C. martini, C. ambrosioides, C. citratus, T. ammi and A. houstonianum Mill. P. jacquemontiana is an aromatic plant of the Hamamelidaceae family, and is well-recognized for its medicinal value, especially in terms of treating skin infections or eruptions, relieving body aches and minimizing dermatitis, along with its anti-inflammatory, antioxidant hepatoprotective activities, as shown in experimental rats [111-113]. The study revealed excellent antifungal characteristics of P. jacquemontiana EO against seven fungi and one yeast strain. The maximum inhibition zone was obtained with Mucor piriformis ATCC $52554(19.83 \pm 1.04 \mathrm{~mm})$, while $F$. solani ATCC 36031 resulted in a minimum inhibition zone of $13.13 \pm 1.03 \mathrm{~mm}$ and a maximum MIC value of $512 \mu \mathrm{g} / \mathrm{mL}$ [89].

The properties of this oil with a wide spectrum of antifungal capacity were believed to be strongly influenced by its chemical composition, i.e., mostly phenolic compounds. 
Past research has suggested that alcohols, phenolic compounds or aldehydes are capable of preventing fungi and yeast growth [114]. An in vivo study to evaluate the wound healing capacity of this EO was performed with Sprague-Dawley rats. Outstanding wound contraction rates were observed. This phenomenon was attributed to the presence of phytochemical compounds (phenolic compounds, flavonoids, terpenoids, alkaloids) which were reported previously to assist in wound contraction and facilitate epithelialization. Wound healing encompasses a critical step of increased proliferation and migration over the wound via re-epithelialization, that further strengthens this hypothesis [115]. Although P. jacquemontiana oil was presented as an effective approach for wound healing, this group of researchers also proposed that extended studies with regards to the mechanism involved should be undertaken in the future [89].

In another study, the capacity of T. ammi fruits EO was demonstrated for antidermatophytic activity using Swiss Albino mice model. T. ammi L. is a member of the Apiaceae family, that was known as an aromatic herb and spice grown in Egypt, Persia, Bangladesh, Afghanistan, Ethiopia and India [116]. These fruits possess numerous medicinal properties, including antimicrobial, anti-inflammatory, antioxidant, antiviral and anticandidal effects [117-122]. Chemical profiling of the oil revealed thymol as the major component, at $58.88 \%$, followed by p-cymene (24.02\%) and $\gamma$-terpinene (13.77\%). The MIC value of T. ammi oil was noted in the range of $0.025-0.5 \mu \mathrm{L} / \mathrm{mL}$ against tested fungi. Maximum zone of inhibition was observed against $C$. tropicum $(63.83 \pm 0.166 \mathrm{~mm})$ followed by $T$. simii $(57 \pm 0.288 \mathrm{~mm})$, T. rubrum $(51.33 \pm 0.333 \mathrm{~mm})$ and C. indicum $(45 \pm 0.577 \mathrm{~mm})$. From a total of five concentrations tested, no irritations were observed at low concentrations, i.e., up to $3 \%$, while three mice presented symptoms of mild erythema and all five mice exhibited well-defined erythema at $5 \%$ and $7 \%$ concentrations, respectively. This finding concluded that toxic side effects were not demonstrated at low concentrations. Based on the excellent antidermatophytic activity of the oil, T. ammi $\mathrm{EO}$ could be potentially used in the treatment of tinea or ringworm infections [90].

An EO originating from A. houstonianum Mill leaves was shown to be capable of inhibiting the growth of both M. gypseum and T. mentagrophytes, with MIC of $80 \mu \mathrm{g} / \mathrm{mL}$. A. houstonianum is an annual or biannual herb and a member of the Asteraceae family, that has been utilized as a traditional medicine in many countries. The MIC value of $A$. houstonianum Mill EO when tested with multiple serial dilutions was $20 \mu \mathrm{g} / \mathrm{mL}$ for both (8:2) while 8 and $10 \mu \mathrm{g} / \mathrm{mL}$ value were obtained for M. gypseum and T. mentagrophytes (10:1), respectively. An in vivo study of the acute dermal toxicity effects with guinea pig indicated no changes in treated skin and fur, appearance along with the absence of diarrhea. In addition, dosage increase resulted in a reduction of noise sensitivity degree, pinch reaction, locomotion effects, as well as reactivity. However, a slight darkening of the liver, kidneys and heart was noticed with dosage increase. The observed effects indicated the suitability of A. houstonianum $\mathrm{EO}$ as an antidermatophytic compound. This supported a previous hypothesis that this EO may have depressant or sedative effects on the CNS at high doses [92,123].

C. citratus (DC.) Stapf (Poaceae family), commonly known as lemon grass, is a perennial tropical grass with thin, long leaves. It is one of the main medicinal and aromatic plants cultivated in Algeria, as well as in the tropical and sub-tropical regions of Asia, South America, and Africa [124]. C. citratus EO (LGEO) exhibits promising antifungal effect against $C$. albicans, $C$. tropicalis and $A$. niger, with different inhibition zone diameters (IZD), i.e., $35-90 \mathrm{~mm}$, that increase proportionately with the increase in the oil volume. A chemical characterization of LGEO indicated the presence of geranial and neral as the major components, representing about 42.2 and $31.5 \%$, respectively; its antifungal activity was associated with the presence of these compounds. The diameter of the growth inhibition zone (DGIZ) of LGEO in the vapor phase was found to be superior to the liquid phase, which is believed to be more advantageous in terms of application ease, elimination of the need for direct contact with the oil, and the requirement of using less oil. In vivo evaluation with Swiss albino mice showed considerable anti-inflammatory activity, where 
the degree of edema inhibition was similar for 10 and $100 \mathrm{mg} / \mathrm{kg}$ LGEO $90 \mathrm{~min}$ after oral administration ( 82.75 and $86.2 \%$, respectively). This level of edema inhibition was comparable to that observed using $50 \mathrm{mg} / \mathrm{kg}$ oral doses of the standard reference drug, diclofenac $(86.2 \%)$. The analysis of the inhibition degree of croton oil topical application resulted in noticeable edema on the left ear. On the whole, LGEO, as an antifungal and anti-inflammatory agent, is believed to be effective, both in the prevention and treatment of acute inflammatory skin conditions. In line with this potential, this research introduced ideas for additional evaluations of active constituents, specific action mechanisms and drug discovery for alternative antifungal therapies [91].

Commonly used antifungal methods include the disc diffusion technique, macro and microbroth dilution assays, the food poisoning method, the volatile release plate method, as well as the use of electron microscopy. Certain methods like disc diffusion, well diffusion and agar dilution methods have been shown to produce unreliable and inconsistent results $[125,126]$; this is primarily due to difficulties related to stable oil dispersion in aqueous media, lipophilic substance distribution in the aqueous medium, and various methods which are used to determine the number of viable microbes that will remain following the addition of EOs. In addition, true representation of activity is not possible with the disc and well diffusion methods, as different components diffuse through the agar at varying rates, and only the more water-soluble components, such as terpine 4-ol, are capable of agar penetration [125]. This phenomenon also occurs in the agar dilution method, where the incorporation of EO into agar can result in the loss of certain active compounds (e.g. terpinen-4-ol, linalool and limonene), either through evaporation or absorption into the petri dish plastic [127]. These techniques yield unreproducible outcomes for certain EOs, and are thus unreliable for assessments of the true behaviour of EOs. Usually, Tween 80 (a commercial polyoxyethylene sorbitan monooleate) will be added to emulate the oils for the study of the antifungal activity of hydrophobic and viscous EOs [128]. This may be linked to the fact that surfactants decrease the degradation rates of EOs, thereby causing the continued release of antimicrobial agents [129].

\subsection{EOs in Nonconventional Approaches}

Nonconventional technology is defined as a combinatorial approach of an EO with an absorption base (e.g., ointments). This approach was applied in one study that examined the effect of L. multifora (Lippia oil) in combination with six types of ointment base and incorporation of Tween 80 at four different concentrations to another set. The findings of this study revealed that the most effective inhibitory action was obtained when lippia oil $(10 \% w / w)$ was combined with Hydrous Wool Fat Ointment BP (British Pharmacopoeia method) or Simple Ointment BP, with added Tween $80(6 \% w / w)$ upon testing of C. pseudotropicalis and C. albicans. The incorporation of Tween 80 further enhanced the efficacy of this formulation, suggesting its suitability as a nonconventional treatment strategy [85].

The potential of $P$. betle EO in combination with polymer gel as a suitable dermatological formulation against multiple skin pathogens was studied. The reported results showed the highest sensitivity of $C$. albicans and $A$. niger toward $P$. betle EO, with inhibition up to $24 \mathrm{~mm}$ and $20 \mathrm{~mm}$ when tested at $20 \mu \mathrm{L}$ concentrations, respectively. The inhibition zones were found to be less affected by gel incorporation, as confirmed by the antimicrobial results from the use of the final formulation [56]. Another potential treatment of candidiasis was tested on B. tripartita. An EO of B. tripartita (BTEO) was obtained via hydrodistillation of the aerial parts of the plant, which were then transformed into a gel formulation. The authors of this study concluded that both active phytoconstituents of $B$. tripartita, as well as the vehicle properties of the gel, contributed to the observed therapeutic activity. The highest inhibition was recorded on C. tropicalis and C. krusei with $3.7 \mathrm{~mm}$ difference compared to hydrogel without BTEO. Through the comparison, the hydrogel-based formulation combined with BTEO appeared to be the preferred mixture, exhibiting superior antifungal activity against all tested Candida strains and revealing the oil as a promising anticandidal agent [86]. 
Another study screened the potential of nine EOs, where B. serrata was cited for its superior activity, with maximal activity against Trichophyton spp. B. serrata EO was reported to contain mostly of $\alpha$-thujene, $\rho$-cymene and sabinene compounds. The synergistic activity demonstrated with azoles in azole-resistant $C$. albicans indicated the suitability of this oil for use as an antifungal agent. However, as the study was limited in terms of its examination of the mechanism of action, individual constituent analyses and clinical studies, further investigations were deemed necessary [78]. Similarly, the antifungal activity of several EOs (black pepper, cardamom, cumin, Boswellia and Patcholi) were examined in another study against fluconazole-resistant fungi. The results revealed the effectiveness of Boswellia and Cardamom oil against $C$. tropicalis and T. mentagrophytes, respectively. Furthermore, a synergistic effects of a combination of Boswellia $\mathrm{EO}$ and fluconazole was noted, revealing itself to be the most effective of the applied approaches against $C$. tropicalis, even at 1:10 dilution and $100 \mu \mathrm{g} / \mathrm{mL}$, respectively. As indicated by Sadhasivam and colleagues [78], an earlier study also proposed that the active compound, action mechanism, toxicity and stability be the focus of future investigations [88].

R. officinalis, Lavandula $x$ intermedia "Sumian" and O. vulgare subsp. hirtum are among the most common medicinal plants in the Mediterranean region. They were widely used and have been synergistically tested for the treatment of candidiasis. Research on the HaCaT (normal cell line) and A431 (tumoral cell line) reported its safety for use as an antiproliferative agent. In vitro studies against $C$. albicans, $C$. krusei and C. parapsilosis showed an increase in the antifungal activity of clotrimazole-loaded nanoparticles (NLC). NLC containing Mediterranean EOs represents a promising strategy to improve drug effectiveness against topical candidiasis [87]. Infection of hair, globous skin and nails on humans is believed to be caused by keratinophilic fungi. Four types of an available commercial formulation called Itra-Bella (Lonicera $x$ bella zabel), Kewda (P. odoratissimus), Rajnigandha ( $P$. tuberosa) and Mogra (J. sambac) were tested against $A$. flavus, T. mentagrophytes, T. tonsurans, T. verrucosum, E. floccosum and M. nanum. The results showed better antifungal activity with EOs compared to synthetic drugs, i.e., terbinafine, itraconazole and fluconazole. T. tosurans was inhibited up to $47 \mathrm{~mm}$ by Itra-Bella, indicating that keratinophilic fungi could be successfully inhibited by Itra-Bella [62].

Several combination studies with in vitro and in vivo approaches also evaluated nonconventional technologies. One example is a study that investigated the potential of LGEO using nonconventional technology that incorporated the formulation of a topical hydrogel with lemongrass-loaded nano-sponges for antifungal action against C. albicans strain ATC 100231. Nano-sponges are a novel class of encapsulated nanoparticles that serves as an excellent delivery system in both the pharmaceutical and cosmeceutical industries [130]. This technology has received much attention in recent years, as it combines the benefits of both microsponges and nanosized-mediated delivery systems. Nanosponges with topical hydrogels have been shown to cause minimal irritation, fewer adverse effects as well as improved skin retention when compared with conventional topical delivery systems $[57,131]$. Similarly, this nonconventional approach was proven to be effective, i.e., the results confirmed the superior nonirritant and antifungal effects of the final selected hydrogel (F9) from among nine tested formulations. The MIC and MFC concentrations of LGEO using the broth macrodilution method was found to be 2 and $8 \mu \mathrm{L} / \mathrm{mL}$, respectively. The results were promising, especially for the practical approach of using pharmaceutical formulations as a measure to minimize the risk of folk medicine usage in the crude form [93].

Another study by Gemeda and others conducted with EO from C. martini showcased broad-spectrum antimicrobial potency against all tested organisms, with MIC value ranging from 0.65 to $10 \mu \mathrm{g} / \mathrm{mL}$. C. martini EO demonstrated absolute growth inhibitions of Trichophyton mentagrophytes and T. rubrum ( $>1 \%$ EO concentration), as well as M. canis and T. verrucosum ( $>4 \%$ EO concentration) [94]. This study incorporated a nonconventional approach, whereby various formulations were prepared and tested. A total of five base formulations (hydrophilic ointment, macrogol blend ointment, macrogol cream, simple ointment and white petrolatum base) were prepared with different concentrations of the 
EO by incorporating the oil into soft mass of different dermatological bases. The findings demonstrated that both hydrophilic and macrogol blend ointments with C. martini EO demonstrated superior activity upon tested organisms than relevant commercial drugs. Furthermore, a skin sensitization test with guinea pig showed no sign of irritation or sensitization when tested with $5 \%$ EO topical formulation. Hence, this product was believed to be a suitable alternative to established treatments, although extended studies are required to evaluate the safety, chronic toxicity and efficacy [94].

One more interesting study described the antifungal activity of C. martini and C. ambrosioides $\mathrm{EO}$, along with their combinations, against several dermatophytes and filamentous fungi via in vitro as well as in vivo (guinea pig) tests. C. martini belongs to the Poaceae family, and is a known medicinal plant that possesses thermogenic, diuretic and insecticidal activity $[132,133]$. C. ambrosioides $\mathrm{L}$. is a member of the Chenopodiaceae family and is widely used in Indian traditional medicines. Its antifungal and antiaflatoxigenic activities have been noted against certain storage fungi [51,132]. Its EO was prepared by mixing $1 \mathrm{~mL}$ of the oil with $100 \mathrm{~g}$ petroleum jelly. An in vivo study indicated significant efficacy of the EO against superficial mycosis, with a reduction in skin redness, lesion severity and dermatophyte occurrence upon ointment application, as confirmed via recurrence of hair growth at the infected site, compared to the control. The disease was successfully removed within 7-21 days via the application of EO ointments [95].

In addition, in vitro evaluation of both EO also inhibited the growth of T. rubrum and M. gypseum, with low MIC values that signified their potential role as alternatives to synthetic antifungal drugs. A chemical characterization indicated the presence of transgeranoil $(60.9 \%)$ and $\mathrm{m}$-cymene $(43.9 \%)$ as the major components of $C$. martini oil and C. ambrosioides EOs, respectively. One important element in this study was the more efficient synergistic effect obtained with a combination of both EOs in a 1:1 ratio than C. ambrosioides alone, indicating fungitoxicity alteration effects with the formation of combined chemical profiles. The MIC of EO and combination were shown to be around 150-500 ppm, which was comparatively lower than those of commercial drugs, which are usually higher, at around 1000-5500 ppm. In conclusion, this study highlighted the ability of both EOs, individually or in combination, to serve as a suitable strategy in the treatment of various superficial mycoses in humans, and recommended that clinical trials be performed [95].

\subsection{EOs in Clinical Interventions}

The effectiveness of EOs for the treatment of skin fungus has also been investigated through clinical interventions, in addition to in vitro and in vivo studies. In our review, we came across two interesting clinical research projects that had evaluated the antifungal activity of EOs originating from distinct plant species. In the first intervention, the antifungal activity of M. communis EO against Malassezia sp. isolated from the skin of patients with Pityriasis versicolor was examined. Malassezia sp. is a class of lipophilic yeasts that covers part of the skin microflora in humans and other warm-blooded animals [134]. However, the presence of this yeast is also known to lead to diseases such as inflammation, systemic infections or uninflamed lesions. Among these, uninflamed lesions in the presence of excess fungal load represent a disease known as Pityriasis versicolor (PV) [134,135]. PV is sometimes also known as tinea versicolor, and is characterized by the development of hypo or hyperpigmented scaly spots $[134,136]$.

Malassezia furfur is recognized as one of the main causative agents of PV, from among the 14 recognized Malassezia species $[134,135]$. The EO applied in this study was isolated from Myrtus communis (Myrtaceae), which has been widely used in various medicinal remedies. To date, this myrtle EO is known to contain 1, 8-cineole and $\alpha$-pinene. Its antifungal activity against several species (e.g. Rhizoctonia solani, F. solani, A. flavus, Colletotrichum lindemuthianum, F. culmorum, C. albicans) [137-140] has been documented. In this prospective case-series study, clinical isolates of PV were collected from 41 patients that had been deprived of treatment for at least two weeks. The clinical samples revealed the presence of 86 yeast colonies with seven identified species: M. furfur $(42.5 \%)$, M. sympo- 
dialis $(23.5 \%)$, M. sllooffiae (13.9\%), M. globose (7.5\%), M. obtusa (6\%), M. japonica (4\%) and $M$. restricta $(2.5 \%)$. The antifungal inhibition revealed excellent activity of $M$. communis against Malassezia sp., especially M. furfur and M. sympodialis, at $96 \%$ and $83 \%$, respectively. The findings of this study suggest the potential of $M$. communis EO as an alternative to conventional antifungal drugs, especially in the treatment of PV. Such an approach was considered cheaper, safe and nonhepatotoxic or nonnephrotoxic. Nevertheless, this study also addressed its limitations, and proposed the need for in vivo studies to confirm the effectiveness of this EO [97].

The second investigation focused on the antifungal activity of EO obtained from C. longa L. waste leaves. Curcuma longa L. is a member of the Zingiberaceae family that grows mostly in Sri Lanka, Indonesia and many parts of India. Curcuma longa L. is usually called turmeric, haldi or Indian saffron, with well-known usage as a spice, as well as a treatment against common skin diseases [141]. In a study by Pandey and colleagues, Curcuma longa L. EO exhibited positive effects against several human pathogenic fungi (Pandey et al. 2010). The selected patients in this study had been diagnosed with Tinea corporis. Tinea corporis is classified as a form of dermatophytic infection of glabrous skin. Trichophyton and Microsporum species were identified as the cause of this infection. Tinea corporis infection generally occurs within the stratum corneum of the epidermis, and may be transmitted via direct contact with infected individuals or animals [96,142,143].

Chemical characterization of the oil indicated the presence of terpinolene, $\alpha$-phellendren, terpinen-4-ol and sabinyl acetate as the main components. It was also noted that the oil destroyed both $M$. gypseum and T. mentagrophytes within $5 \mathrm{~s}$. In addition, antifungal activity of the oil was observed with other species such as E. floccosum, M. nanum, T. rubrum and T. violaceum. This study highlighted the significant potential of $C$. longa leaf EO based on in vitro and in vivo assays; additionally, strong fungicidal action, extended shelf-life, tolerability of higher inoculum density, thermal stability and a wider range of antidermatophytic activity without any adverse effects were noted. Intervention studies that involved the topical application of the oil formulation gave positive insights into its efficacy; complete healing was observed in $72 \%$ of cases after three weeks of treatment, without any relapse when patients were examined two months later. Hence, the study proposed the application of C. longa leaf EO as an inexpensive and effective formulation for commercial use [96].

\subsection{EOs in Other Nonconventional Approaches and Their Advantages}

The development of numerous nonconventional approaches in antifungal therapies indicates great potential. In addition to the reviewed articles, one prominent technique that has gained attention is the application of cyclodextrins via encapsulation. This technique involves the formation of inclusion complexes of selected oils with cyclodextrins (CDs). In a study performed by Torres-Alvarez and colleagues, concentrated orange oils were subjected to encapsulation with $\beta-C D$ and evaluated for their antifungal activity. This study noted that the highest antifungal activity inhibition was achieved at $10 \mathrm{mg} / \mathrm{mL}$, respective to $10 \times$ fraction orange oil in ratios of 12:88 and 16:84 (COEO: $\beta-C D)$. Hence, the encapsulation technique proved to be beneficial toward inhibition, although the researchers proposed further studies to confirm the formation of the complex and the encapsulated compounds [144].

Pickering emulsions (PEs) are widely sought after at present, compared to conventional emulsions. PEs comprise particle-stabilized emulsions in which solid particles tend to adsorb instantly on the oil-water interface, resulting in a shell-like structure on the PE droplet surface. There are various advantages associated with the PE approach, e.g., improved stability in relation to the higher adsorption energy of solid particles, as well as appropriate emulsion droplet size, that could assist in longer retention of the antifungal drug at the treatment site. The approach of PE was demonstrated in one study that evaluated its effectiveness as an alternative therapy for onychomycosis topical treatment, also known as fungal nail infections. For this purpose, a nanotechnological approach was applied to formulate PEs in combination with azole derivative 
(tioconazole) and Melaleuca alternifolia EO tested against $C$. albicans and T. rubrum. The findings showed that PEs are an excellent choice for onychomycosis topical treatment compared to conventional emulsions or ethanolic solutions of reference drugs [145].

Nonconventional techniques are have gained broader recognition in recent years due to their excellent benefits. In this review, we have discussed various nonconventional approaches, and noted their superiority compared to the traditional methods. In general, we would like to highlight the fact that strategies involving nonconventional treatments are useful to reduce risks associated with the crude forms of folk medicines, along with lesser adverse effects and higher skin retention for better targeted drug delivery.

\section{Materials and Methods}

\section{Search Strategy}

Original articles were identified through searches of three databases (PubMed, WoS and Google Scholar) for the period of 2010 to 2020 using ("skin"[MeSH Terms] OR "skin"[All Fields]) AND ("antifungal agents"[Pharmacological Action] OR "antifungal agents"[MeSH Terms] OR ("antifungal"[All Fields] AND "agents"[All Fields]) OR “antifungal agents"[All Fields] OR "antifungal"[All Fields] OR "antifungals"[All Fields] OR "antifungic"[All Fields] OR "antifungical"[All Fields]) AND ("oils, volatile"[MeSH Terms] OR ("oils"[All Fields] AND "volatile"[All Fields]) OR "volatile oils"[All Fields] OR ("essential"[All Fields] AND "oil"[All Fields]) OR "essential oil"[All Fields]). Publications with abstracts were reviewed; the search was limited to studies published in the English and Malay languages. Papers on in vitro, in vivo, human and animal studies, and related to plant-based antifungal medication were included. Review articles and letters to the editor were excluded. Duplicate articles were eliminated.

\section{Conclusions}

In conclusion, our review underlines the fact that the importance of antifungal agents EOs is widely recognized. Their roles in reducing the severity of fungal infections vary according to species and origin. Based on our review, we strongly believe that EOs should be explored for commercial applications as alternatives to over-the-counter antifungal agents. In addition, commercial applications could be further enhanced with nonconventional strategies in combination with other components, such as fluconazole and Tween 80 . Hence, it is vital that efforts continue for the development of EO-based skin antifungal therapies.

Author Contributions: Conceptualization: all authors; literature review: all authors; tables: all authors, writing and review all authors; editing: all authors; revisions and final editing: all authors. All authors have read and agreed to the published version of the manuscript.

Funding: This research received no external funding.

Acknowledgments: The authors thank the Director General of Health Malaysia and the Director of Institute for Medical Research (IMR), Malaysia, for giving the permission to publish this article. We also thank the staff of Nutrition, Metabolism and Cardiovascular Centre, Institute for Medical Research, NIH for their continuous support.

Conflicts of Interest: The authors declare no conflict of interest. 


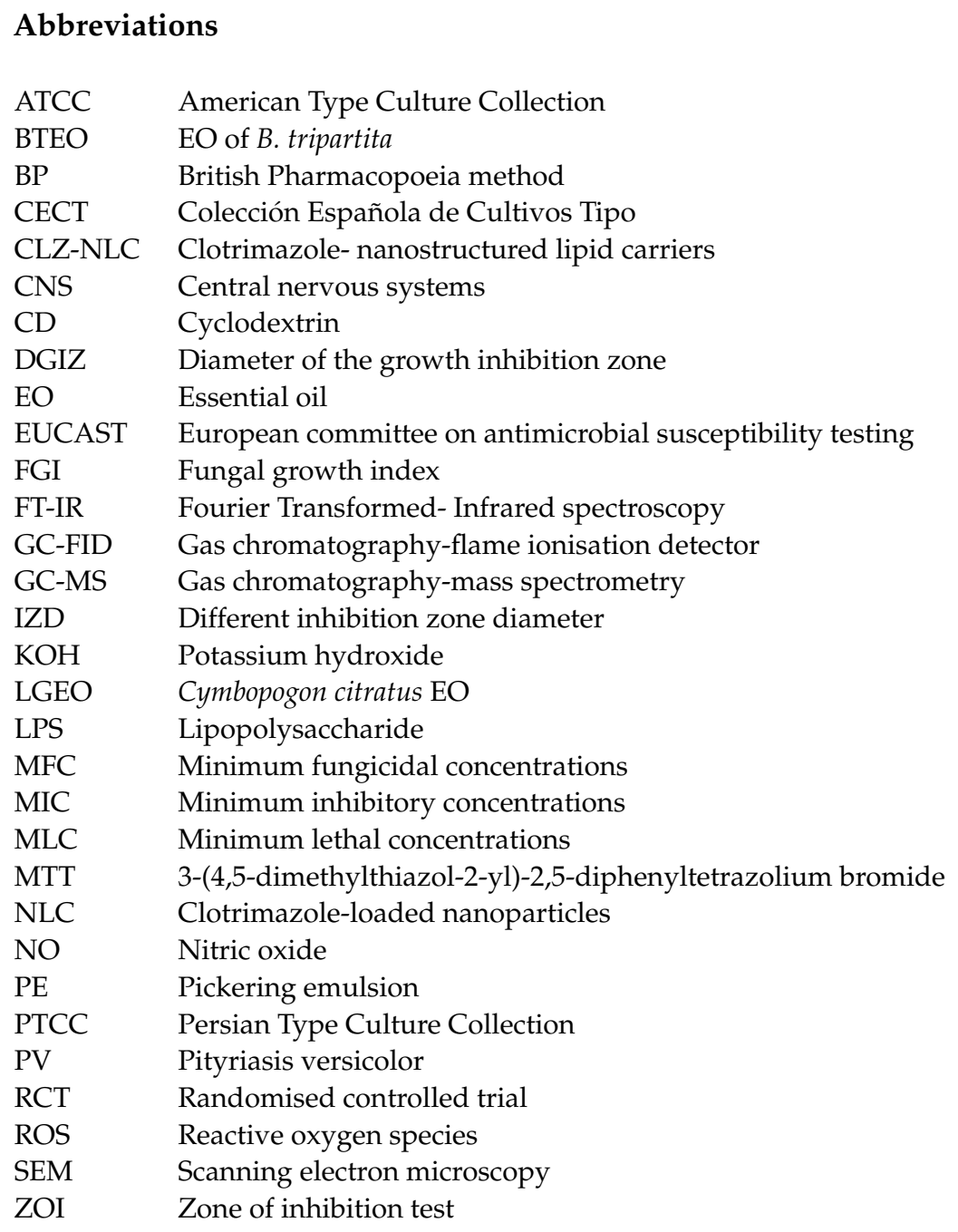

\section{References}

1. Guarner, J.; Brandt, M.E. Histopathologic diagnosis of fungal infections in the 21st century. Clin. Microbiol. Rev. 2011, 24, 247-280. [CrossRef]

2. Natu, K.N.; Tatke, P.A. Essential oils_Prospective candidates for antifungal treatment? J. Essent. Oil Res. 2019, 31, 347-360. [CrossRef]

3. Warnock, D.W. Trends in the epidemiology of invasive fungal infections. Nihon Ishinkin Gakkai Zasshi Jpn. J. Med. Mycol. 2007, 48, 1-12. [CrossRef]

4. Yoon, H.J.; Choi, H.Y.; Kim, Y.K.; Song, Y.J.; Ki, M. Prevalence of fungal infections using National Health Insurance data from 2009-2013, South Korea. Epidemiol. Health 2014, 36, 1-10. [CrossRef]

5. Weiskopf, D.; Weinberger, B.; Grubeck-Loebenstein, B. The aging of the immune system. Transpl. Int. 2009, 22, 1041-1050. [CrossRef]

6. Singh, N. Trends in the epidemiology of opportunistic fungal infections: Predisposing factors and the impact of antimicrobial use practices. Clin. Infect. Dis. 2001, 33, 1692-1696. [CrossRef] [PubMed]

7. Nucci, M.; Marr, K.A. Emerging fungal diseases. Clin. Infect. Dis. 2005, 41, 521-526. [CrossRef]

8. Riscili, B.P.; Wood, K.L. Noninvasive pulmonary Aspergillus infections. Clin. Chest Med. 2009, 30, 315-335, vii. [CrossRef]

9. Garbino, D.J. Aspergillosis. In Orphanet Encyclopedia; Lew, D., Ed.; Orphanet: Paris, France, 2004; pp. 1-7.

10. Dignani, M.C.; Anaissie, E. Human fusariosis. Clin. Microbiol. Infect. 2004, 10 (Suppl. 1), 67-75. [CrossRef] [PubMed]

11. Godoy, P.; Nunes, E.; Silva, V.; Tomimori-Yamashita, J.; Zaror, L.; Fischman, O. Onychomycosis caused by Fusarium solani and Fusarium oxysporum in São Paulo, Brazil. Mycopathologia 2004, 157, 287-290. [CrossRef]

12. Brilhante, R.; Cordeiro, R.; Medrano, D.; Rocha, M.; Monteiro, A.; Cavalcante, C.; Meireles, T.; Sidrim, J. Onychomycosis in Ceará (Northeast Brazil): Epidemiological and laboratory aspects. Mem. Inst. Oswaldo Cruz 2005, 100, 131-135. [CrossRef] [PubMed]

13. Ninet, B.; Jan, I.; Bontems, O.; Léchenne, B.; Jousson, O.; Lew, D.; Schrenzel, J.; Panizzon, R.G.; Monod, M. Molecular identification of Fusarium species in onychomycoses. Dermatology 2005, 210, 21-25. [CrossRef] 
14. Vazquez, J.A.; Sobel, J.D. Candidiasis. In Essentials of Clinical Mycology; Kauffman, C.A., Pappas, P.G., Sobel, J.D., Dismukes, W.E., Eds.; Springer: New York, NY, USA, 2011; pp. 167-206.

15. Darouiche, R.O. Candida in the ICU. Clin. Chest Med. 2009, 30, 287-293. [CrossRef] [PubMed]

16. Bommanavar, S.; Gugwad, S.; Malik, N. Phenotypic switch: The enigmatic white-gray-opaque transition system of Candida albicans. J. Oral Maxillofac. Surg. Med. Pathol. 2017, 21, 82-86. [CrossRef]

17. Chakrabarti, A.; Sood, P.; Rudramurthy, S.M.; Chen, S.; Kaur, H.; Capoor, M.; Chhina, D.; Rao, R.; Eshwara, V.K.; Xess, I.; et al. Incidence, characteristics and outcome of ICU-acquired candidemia in India. Intensiv. Care Med. 2015, 41, 285-295. [CrossRef]

18. Noble, S.L.; Forbes, R.C.; Stamm, P.L. Diagnosis and management of common tinea infections. Am. Fam. Physician 1998, 58, 163-174, 177-178. [PubMed]

19. Aguilar, C.V.J.; Alanio, A.S.B.; Frange, P.; Lanternier, F.; Lortholary, O. Antifungals. Available online: https://www.em-consulte. com/article/946740/antifongiques (accessed on 24 December 2020).

20. Chanthaphon, S.; Chanthachum, S.; Hongpattarakere, T. Antimicrobial activities of essential oils and crude extracts from tropical Citrus spp. against food-related microorganisms. Songklanakarin J. Sci. Technol. 2008, 30, 125-131.

21. Da Cruz Cabral, L.; Fernández Pinto, V.; Patriarca, A. Application of plant derived compounds to control fungal spoilage and mycotoxin production in foods. Int. J. Food Microbiol. 2013, 166, 1-14. [CrossRef]

22. Sharifi-Rad, J.; Sureda, A.; Tenore, G.C.; Daglia, M.; Sharifi-Rad, M.; Valussi, M.; Tundis, R.; Sharifi-Rad, M.; Loizzo, M.R.; Ademiluyi, A.O.; et al. Biological Activities of Essential Oils: From Plant Chemoecology to Traditional Healing Systems. Molecules 2017, 22, 70. [CrossRef]

23. Rajkowska, K.; Otlewska, A.; Kunicka-Styczyńska, A.; Krajewska, A. Candida albicans Impairments Induced by Peppermint and Clove Oils at Sub-Inhibitory Concentrations. Int. J. Mol. Sci. 2017, 18, 1307. [CrossRef]

24. Tullio, V.; Roana, J.; Scalas, D.; Mandras, N. Evaluation of the Antifungal Activity of Mentha x piperita (Lamiaceae) of Pancalieri (Turin, Italy) Essential Oil and Its Synergistic Interaction with Azoles. Molecules 2019, 24, 3148. [CrossRef] [PubMed]

25. Tullio, V.; Roana, J.; Scalas, D.; Mandras, N. Enhanced Killing of Candida krusei by Polymorphonuclear Leucocytes in the Presence of Subinhibitory Concentrations of Melaleuca alternifolia and "Mentha of Pancalieri" Essential Oils. Molecules 2019, $24,3824$. [CrossRef] [PubMed]

26. Scalas, D.; Mandras, N.; Roana, J.; Tardugno, R.; Cuffini, A.M.; Ghisetti, V.; Benvenuti, S.; Tullio, V. Use of Pinus sylvestris L. (Pinaceae), Origanum vulgare L. (Lamiaceae), and Thymus vulgaris L. (Lamiaceae) essential oils and their main components to enhance itraconazole activity against azole susceptible/not-susceptible Cryptococcus neoformans strains. BMC Complement. Altern. Med. 2018, 18, 143. [CrossRef]

27. D'Agostino, M.; Tesse, N.; Frippiat, J.P.; Machouart, M.; Debourgogne, A. Essential Oils and Their Natural Active Compounds Presenting Antifungal Properties. Molecules 2019, 24, 3713. [CrossRef] [PubMed]

28. Pinto, E.; Pina-Vaz, C.; Salgueiro, L.; Gonçalves, M.J.; Costa-de-Oliveira, S.; Cavaleiro, C.; Palmeira, A.; Rodrigues, A.; Martinezde-Oliveira, J. Antifungal activity of the essential oil of Thymus pulegioides on Candida, Aspergillus and dermatophyte species. J. Med. Microbiol. 2006, 55, 1367-1373. [CrossRef]

29. Omidbeygi, M.; Barzegar, M.; Hamidi, Z.; Naghdibadi, H. Antifungal activity of thyme, summer savory and clove essential oils against Aspergillus flavus in liquid medium and tomato paste. Food Control 2007, 18, 1518-1523. [CrossRef]

30. Rasooli, I.; Rezaei, M.B.; Allameh, A. Growth inhibition and morphological alterations of Aspergillus niger by essential oils from Thymus eriocalyx and Thymus x-porlock. Food Control 2006, 17, 359-364. [CrossRef]

31. Khan, M.S.; Ahmad, I. In vitro antifungal, anti-elastase and anti-keratinase activity of essential oils of Cinnamomum-, Syzygiumand Cymbopogon-species against Aspergillus fumigatus and Trichophyton rubrum. Phytomedicine 2011, 19, 48-55. [CrossRef]

32. Khan, M.S.; Ahmad, I. Antifungal activity of essential oils and their synergy with fluconazole against drug-resistant strains of Aspergillus fumigatus and Trichophyton rubrum. Appl. Microbiol. Biotechnol. 2011, 90, 1083-1094. [CrossRef]

33. Angelini, P.; Pagiotti, R.; Menghini, A.; Vianello, B. Antimicrobial activities of various essential oils against foodborne pathogenic or spoilage moulds. Ann. Microbiol. 2006, 56, 65-69. [CrossRef]

34. Vilela, G.R.; de Almeida, G.S.; D’Arce, M.A.B.R.; Moraes, M.H.D.; Brito, J.O.; da Silva, M.F.d.G.; Silva, S.C.; de Stefano Piedade, S.M.; Calori-Domingues, M.A.; da Gloria, E.M. Activity of essential oil and its major compound, 1, 8-cineole, from Eucalyptus globulus Labill., against the storage fungi Aspergillus flavus Link and Aspergillus parasiticus Speare. J. Stored Prod. Res. 2009, 45, 108-111. [CrossRef]

35. Uniyal, V.; Bhatt, R.; Saxena, S.; Talwar, A. Antifungal activity of essential oils and their volatile constituents against respiratory tract pathogens causing Aspergilloma and Aspergillosis by gaseous contact. J. Appl. Nat. Sci. 2012, 4, 65-70. [CrossRef]

36. Verma, R.K.; Chaurasia, L.; Kumar, M. Antifungal activity of essential oils against selected building fungi. Indian J. Nat. Prod. Resour. 2011, 2, 448-451.

37. Pinto, E.; Vale-Silva, L.; Cavaleiro, C.; Salgueiro, L. Antifungal activity of the clove essential oil from Syzygium aromaticum on Candida, Aspergillus and dermatophyte species. J. Med. Microbiol. 2009, 58, 1454-1462. [CrossRef]

38. Naeini, A.; Shokri, H. Chemical composition and in vitro antifungal activity of the essential oil from Cuminum cyminum against various Aspergillus strains. J. Med. Plants Res. 2012, 6, 1702-1706. [CrossRef]

39. Kanafani, Z.A.; Perfect, J.R. Antimicrobial resistance: Resistance to antifungal agents: Mechanisms and clinical impact. Clin. Infect. Dis. 2008, 46, 120-128. [CrossRef] 
40. Low, C.Y.; Rotstein, C. Emerging fungal infections in immunocompromised patients. F1000 Med. Rep. 2011, 3, 14. [CrossRef] [PubMed]

41. Mondello, F.; De Bernardis, F.; Girolamo, A.; Salvatore, G.; Cassone, A. In vitro and in vivo activity of tea tree oil against azole-susceptible and -resistant human pathogenic yeasts. J. Antimicrob. Chemother. 2003, 51, 1223-1229. [CrossRef]

42. Stringaro, A.; Colone, M.; Angiolella, L. Antioxidant, Antifungal, Antibiofilm, and Cytotoxic Activities of Mentha spp. Essential Oils. Medicines 2018, 5, 112. [CrossRef] [PubMed]

43. D'Auria, F.D.; Tecca, M.; Strippoli, V.; Salvatore, G.; Battinelli, L.; Mazzanti, G. Antifungal activity of Lavandula angustifolia essential oil against Candida albicans yeast and mycelial form. Med. Mycol. 2005, 43, 391-396. [CrossRef] [PubMed]

44. Behmanesh, F.; Pasha, H.; Sefidgar, A.A.; Taghizadeh, M.; Moghadamnia, A.A.; Adib Rad, H.; Shirkhani, L. Antifungal Effect of Lavender Essential Oil (Lavandula angustifolia) and Clotrimazole on Candida albicans: An In Vitro Study. Scientifica (Cairo) 2015, 2015, 1-5. [CrossRef]

45. Minooeianhaghighi, M.H.; Sepehrian, L.; Shokri, H. Antifungal effects of Lavandula binaludensis and Cuminum cyminum essential oils against Candida albicans strains isolated from patients with recurrent vulvovaginal candidiasis. J. Mycol. Med. 2017, 27, 65-71. [CrossRef]

46. Dhifi, W.; Bellili, S.; Jazi, S.; Bahloul, N.; Mnif, W. Essential Oils' Chemical Characterization and Investigation of Some Biological Activities: A Critical Review. Medicines 2016, 3, 25. [CrossRef] [PubMed]

47. Dias Ferreira, F.; Mossini, S.A.; Dias Ferreira, F.M.; Arrotéia, C.C.; da Costa, C.L.; Nakamura, C.V.; Machinski, M., Jr. The inhibitory effects of Curcuma longa L. essential oil and curcumin on Aspergillus flavus link growth and morphology. Sci. World J. 2013, 2013, 1-6. [CrossRef]

48. Tolouee, M.; Alinezhad, S.; Saberi, R.; Eslamifar, A.; Zad, S.J.; Jaimand, K.; Taeb, J.; Rezaee, M.B.; Kawachi, M.; Shams-Ghahfarokhi, M.; et al. Effect of Matricaria chamomilla L. flower essential oil on the growth and ultrastructure of Aspergillus niger van Tieghem. Int. J. Food Microbiol. 2010, 139, 127-133. [CrossRef] [PubMed]

49. Khan, A.; Ahmad, A.; Akhtar, F.; Yousuf, S.; Xess, I.; Khan, L.A.; Manzoor, N. Ocimum sanctum essential oil and its active principles exert their antifungal activity by disrupting ergosterol biosynthesis and membrane integrity. Res. Microbiol. 2010, 161, 816-823. [CrossRef]

50. Chen, Y.; Zeng, H.; Tian, J.; Ban, X.; Ma, B.; Wang, Y. Dill (Anethum graveolens L.) seed essential oil induces Candida albicans apoptosis in a metacaspase-dependent manner. Fungal Biol. 2014, 118, 394-401. [CrossRef] [PubMed]

51. Kumar, R.; Mishra, A.K.; Dubey, N.K.; Tripathi, Y.B. Evaluation of Chenopodium ambrosioides oil as a potential source of antifungal, antiaflatoxigenic and antioxidant activity. Int. J. Food Microbiol. 2007, 115, 159-164. [CrossRef]

52. Yahyaraeyat, R.; Khosravi, A.; Shahbazzadeh, D.; Khalaj, V. The potential effects of Zataria multiflora Boiss essential oil on growth, aflatoxin production and transcription of aflatoxin biosynthesis pathway genes of toxigenic Aspergillus parasiticus. Braz. J. Microbiol. 2013, 44, 649-655. [CrossRef]

53. De Oliveira Lima, M.I.; Araújo de Medeiros, A.C.; Souza Silva, K.V.; Cardoso, G.N.; de Oliveira Lima, E.; de Oliveira Pereira, F. Investigation of the antifungal potential of linalool against clinical isolates of fluconazole resistant Trichophyton rubrum. J. Mycol. Med. 2017, 27, 195-202. [CrossRef]

54. Shreaz, S.; Shiekh, R.A.; Raja, V.; Wani, W.A.; Behbehani, J.M. Impaired ergosterol biosynthesis mediated fungicidal activity of Co(II) complex with ligand derived from cinnamaldehyde. Chem. Biol. Interact. 2016, 247, 64-74. [CrossRef] [PubMed]

55. Kurita, N.; Koike, S. Synergistic Antimicrobial Effect of Ethanol, Sodium Chloride, Acetic Acid and Essential Oil Components. Agric. Biol. Chem. 1983, 47, 67-75. [CrossRef]

56. Satpathy, B.; Sahoo, M.; Sahoo, P.; Patra, S. Formulation and evaluation of herbal gel containing essential oils of piper betle against skin infecting pathogens. Int. J. Res. Pharm. Sci. 2011, 2, 373-378.

57. Sharma, R.; Pathak, K. Polymeric nanosponges as an alternative carrier for improved retention of econazole nitrate onto the skin through topical hydrogel formulation. Pharm. Dev. Technol. 2011, 16, 367-376. [CrossRef]

58. Kozics, K.; Bučková, M.; Puškárová, A.; Kalászová, V.; Cabicarová, T.; Pangallo, D. The Effect of Ten Essential Oils on Several Cutaneous Drug-Resistant Microorganisms and Their Cyto/Genotoxic and Antioxidant Properties. Molecules 2019, $24,4570$. [CrossRef] [PubMed]

59. Mahboubi, M.; Kazempour, N. The antifungal activity of Artemisia sieberi essential oil from different localities of Iran against dermatophyte fungi. J. Mycol. Med. 2015, 25, e65-e71. [CrossRef] [PubMed]

60. Khoury, M.; Stien, D.; Eparvier, V.; Ouaini, N.; El Beyrouthy, M. Report on the medicinal use of eleven Lamiaceae species in Lebanon and rationalization of their antimicrobial potential by examination of the chemical composition and antimicrobial activity of their essential oils. Evid. Based Complement. Altern. Med. 2016, 2016, 1-17. [CrossRef]

61. Mary, H.; Tina, A.V.; Jeeja, K.J.; Abiramy, M. Phytochemical analysis and anticancer activity of essential oil from Myristica fragrans. Int. J. Curr. Pharm. Res. 2012, 2, 188-198.

62. Singh, P.; Bundiwale, R.; Dwivedi, L. In-Vitro study of antifungal activity of various commercially available itra (Volatile plant oil) against the keratinophilic fungi isolated from soil. Int. J. Pharma Bio Sci. 2011, 2, 178-184.

63. Gonçalves, M.; Cruz, M.; Cavaleiro, C.; Lopes, M.; Salgueiro, L. Chemical, antifungal and cytotoxic evaluation of the essential oil of Thymus zygis subsp. sylvestris. Ind. Crop. Prod. 2010, 32, 70-75. [CrossRef]

64. Mahboubi, M.; Kazempour, N. Comparison of antifungal activity of different extracts from Satureja khuzistanica Jamzad against dermatophytes. Biharean Biol. 2015, 9, 105-107. 
65. Valente, J.; Zuzarte, M.; Resende, R.; Gonçalves, M.; Cavaleiro, C.; Pereira, C.; Cruz, M.; Salgueiro, L. Daucus carota subsp. gummifer essential oil as a natural source of antifungal and anti-inflammatory drugs. Ind. Crop. Prod. 2015, 65, 361-366. [CrossRef]

66. Abu-Darwish, M.; Cabral, C.; Ferreira, I.; Gonçalves, M.; Cavaleiro, C.; Cruz, M.; Al-Bdour, T.; Salgueiro, L. Essential oil of common sage (Salvia officinalis L.) from Jordan: Assessment of safety in mammalian cells and its antifungal and anti-inflammatory potential. BioMed Res. Int. 2013, 2013, 1-9. [CrossRef]

67. Fahed, L.; Khoury, M.; Stien, D.; Ouaini, N.; Eparvier, V.; El Beyrouthy, M. Essential oils composition and antimicrobial activity of six conifers harvested in Lebanon. Chem. Biodivers. 2017, 14, e1600235. [CrossRef] [PubMed]

68. Tavares, A.C.; Gonçalves, M.J.; Cruz, M.T.; Cavaleiro, C.; Lopes, M.C.; Canhoto, J.; Salgueiro, L.R. Essential oils from Distichoselinum tenuifolium: Chemical composition, cytotoxicity, antifungal and anti-inflammatory properties. J. Ethnopharmacol. 2010, 130, 593-598. [CrossRef]

69. Fajinmi, O.; Kulkarni, M.; Benická, S.; Zeljković, S.Ć.; Doležal, K.; Tarkowski, P.; Finnie, J.; Van Staden, J. Antifungal activity of the volatiles of Agathosma betulina and Coleonema album commercial essential oil and their effect on the morphology of fungal strains Trichophyton rubrum and T. mentagrophytes. S. Afr. J. Bot. 2019, 122, 492-497. [CrossRef]

70. Fajinmi, O.O.; Grúz, J.; Tarkowski, P.; Kulkarni, M.G.; Finnie, J.F.; Van Staden, J. Antifungal and antioxidant activities of Coleonema album and C. pulchellum against skin diseases. Pharm. Biol. 2017, 55, 1249-1255. [CrossRef]

71. Canales-Martinez, M.; Rivera-Yañez, C.; Salas-Oropeza, J.; Lopez, H.; Jimenez-Estrada, M.; Rosas-Lopez, R.; Duran, D.; Flores, C.; Hernandez, L.; Rodriguez-Monroy, M. Antimicrobial activity of Bursera morelensis ramírez essential oil. Afr. J. Tradit. Complement. Altern. Med. 2017, 14, 74-82.

72. Osho, A.; Adetunji, T.; Fayemi, S.O.; Moronkola, D.O. Antimicrobial activity of essential oils of Physalis angulata. L. Afr. J. Tradit. Complement. Altern. Med. 2010, 7, 303-306. [CrossRef]

73. Rezgui, M.; Majdoub, N.; Mabrouk, B.; Baldisserotto, A.; Bino, A.; Kaab, L.B.; Manfredini, S. Antioxidant and antifungal activities of marrubiin, extracts and essential oil from Marrubium vulgare L. against pathogenic dermatophyte strains. J. Mycol. Med. 2020, 100927. [CrossRef] [PubMed]

74. Nyegue, M.A.; Ndoyé-Foe, F.-C.; Essama, S.R.; Hockmeni, T.; Etoa, F.-X.; Menut, C. Chemical composition of essential oils of Eugenia caryophylla and Mentha sp cf piperita and their in vitro antifungal activities on six human pathogenic fungi. Afr. J. Tradit. Complement. Altern. Med. 2014, 11, 40-46. [CrossRef]

75. Cabral, C.; Francisco, V.; Cavaleiro, C.; Gonçalves, M.J.; Cruz, M.T.; Sales, F.; Batista, M.T.; Salgueiro, L. Essential Oil of Juniperus communis subsp. alpina (Suter) Čelak Needles: Chemical Composition, Antifungal Activity and Cytotoxicity. Phytother. Res. 2012, 26, 1352-1357. [CrossRef]

76. Prakash, R.; Agarwal, S.; Srivastava, A.; Nigam, V. GC-MS Analysis of essential oil of Turmeric rhizome and its activity against Sporothrix schenckii fungus. Orient. J. Chem. 2015, 31, 2213-2214. [CrossRef]

77. Dias, N.; Dias, M.; Cavaleiro, C.; Sousa, M.; Lima, N.; Machado, M. Oxygenated monoterpenes-rich volatile oils as potential antifungal agents for dermatophytes. Nat. Prod. Res. 2017, 31, 460-464. [CrossRef] [PubMed]

78. Sadhasivam, S.; Palanivel, S.; Ghosh, S. Synergistic antimicrobial activity of Boswellia serrata Roxb. ex Colebr. (Burseraceae) essential oil with various azoles against pathogens associated with skin, scalp and nail infections. Lett. Appl. Microbiol. 2016, 63, 495-501. [CrossRef]

79. Białoń, M.; Krzyśko-Łupicka, T.; Koszałkowska, M.; Wieczorek, P.P. The influence of chemical composition of commercial lemon essential oils on the growth of Candida strains. Mycopathologia 2014, 177, 29-39. [CrossRef] [PubMed]

80. Rahman, A.; Al-Reza, S.M.; Siddiqui, S.A.; Chang, T.; Kang, S.C. Antifungal potential of essential oil and ethanol extracts of Lonicera japonica Thunb. against dermatophytes. EXCLI J. 2014, 13, 427-436.

81. Tangarife Castaño, V.; Roa Linares, V.; Betancur, L.; Durán, D.; Stashenko, E.; Mesa, A. Antifungal activity of Verbenaceae and Labiatae families essential oils. Pharmacologyonline 2012, 1, 133-145.

82. Sharma, R.; Sharma, G.; Sharma, M. Anti-Malassezia furfur activity of essential oils against causal agent of Pityriasis versicolor disease. Afr. J. Pharm. Pharmacol. 2012, 6, 979-983. [CrossRef]

83. da Cruz, R.C.; Denardi, L.B.; Mossmann, N.J.; Piana, M.; Alves, S.H.; de Campos, M.M. Antimicrobial Activity and Chromatographic Analysis of Extracts from Tropaeolum pentaphyllum Lam. Tubers. Molecules 2016, 21, 566. [CrossRef] [PubMed]

84. Tabassum, N.M.V. Antimicrobial activity of medicinal oil plants against human pathogens from Hyderabad Karnataka Region. Int. J. Pharm. Sci. Rev. Res. 2014, 26, 182-188.

85. Oladimeji, F.A.; Akinkunmi, E.O.; Raheem, A.I.; Abiodun, G.O.; Bankole, V.O. Evaluation of topical antimicrobial ointment formulations of essential oil of Lippia multiflora moldenke. Afr. J. Tradit. Complement. Altern. Med. 2015, 12, 135-144. [CrossRef]

86. Tomczykowa, M.; Wróblewska, M.; Winnicka, K.; Wieczorek, P.; Majewski, P.; Celińska-Janowicz, K.; Sawczuk, R.; Miltyk, W.; Tryniszewska, E.; Tomczyk, M. Novel gel formulations as topical carriers for the essential oil of Bidens tripartita for the treatment of candidiasis. Molecules 2018, 23, 2517. [CrossRef] [PubMed]

87. Carbone, C.; Teixeira, M.d.C.; Sousa, M.d.C.; Martins-Gomes, C.; Silva, A.M.; Souto, E.M.B.; Musumeci, T. Clotrimazole-Loaded mediterranean essential oils NLC: A synergic treatment of Candida skin infections. Pharmaceutics 2019, 11, 231. [CrossRef]

88. Rabadia, A.G.; Kamat, S.; Kamat, D. Antifungal activity of essential oils against fluconazole resistant fungi. Int. J. Phytomed. 2011, 3, 506 .

89. Ali, S.; Khan, M.R.; Batool, R.; Maryam, S.; Majid, M. Wound healing potential of oil extracted from Parrotiopsis jacquemontiana (Decne) Rehder. J. Ethnopharmacol. 2019, 236, 354-365. [CrossRef] [PubMed] 
90. Jain, N.; Sharma, M.; Joshi, S.; Kaushik, U. Chemical composition, toxicity and antidermatophytic activity of essential oil of Trachyspermum ammi. Indian J. Pharm. Sci. 2018, 80, 135-142. [CrossRef]

91. Boukhatem, M.N.; Ferhat, M.A.; Kameli, A.; Saidi, F.; Kebir, H.T. Lemon grass (Cymbopogon citratus) essential oil as a potent anti-inflammatory and antifungal drugs. Libyan J. Med. 2014, 9, 1-10. [CrossRef]

92. Njateng, G.; Kuiate, J.; Gatsing, D.; Tamokou, J.; Mouokeu, R.; Kuete, V. Antidermatophytic activity and dermal toxicity of essential oil from the leaves of Ageratum houstonianum (Asteraceae). J. Biol. Sci. 2010, 10, 448-454. [CrossRef]

93. Aldawsari, H.M.; Badr-Eldin, S.M.; Labib, G.S.; El-Kamel, A.H. Design and formulation of a topical hydrogel integrating lemongrass-loaded nanosponges with an enhanced antifungal effect: In vitro/in vivo evaluation. Int. J. Nanomed. 2015, 10, 893-902.

94. Gemeda, N.; Tadele, A.; Lemma, H.; Girma, B.; Addis, G.; Tesfaye, B.; Abebe, A.; Gemechu, W.; Yirsaw, K.; Teka, F. Development, characterization, and evaluation of novel broad-spectrum antimicrobial topical formulations from Cymbopogon martini (Roxb.) W. Watson essential oil. Evid. Based Complement. Altern. Med. 2018, 2018, 1-16. [CrossRef]

95. Prasad, C.S.; Shukla, R.; Kumar, A.; Dubey, N.K. In vitro and in vivo antifungal activity of essential oils of Cymbopogon martini and Chenopodium ambrosioides and their synergism against dermatophytes. Mycoses 2010, 53, 123-129. [CrossRef]

96. Pandey, K.P.; Mishra, R.K.; Kamran, A.; Mishra, P.; Bajaj, A.K.; Dikshit, A. Studies on antidermatophytic activity of waste leaves of Curcuma longa L. Physiol. Mol. Biol. Plants 2010, 16, 177-185. [CrossRef]

97. Barac, A.; Donadu, M.; Usai, D.; Spiric, V.T.; Mazzarello, V.; Zanetti, S.; Aleksic, E.; Stevanovic, G.; Nikolic, N.; Rubino, S. Antifungal activity of Myrtus communis against Malassezia sp. isolated from the skin of patients with pityriasis versicolor. Infection 2018, 46, 253-257. [CrossRef]

98. Borda, L.J.; Wikramanayake, T.C. Seborrheic Dermatitis and Dandruff: A Comprehensive Review. J. Clin. Investig. Dermatol. 2015, 3, 1-22. [CrossRef]

99. Pugliarello, S.; Cozzi, A.; Gisondi, P.; Girolomoni, G. Phenotypes of atopic dermatitis. JDDG J. Dtsch. Dermatol. Ges. 2011, 9, 12-20. [CrossRef]

100. Gallitano, S.M.; Berson, D.S. How Acne Bumps Cause the Blues: The Influence of Acne Vulgaris on Self-Esteem. Int. J. Womens Dermatol. 2017, 4, 12-17. [CrossRef] [PubMed]

101. Casadevall, A.; Pirofski, L.A. Host-Pathogen interactions: Redefining the basic concepts of virulence and pathogenicity. Infect. Immun. 1999, 67, 3703-3713. [CrossRef]

102. Casadevall, A.; Pirofski, L.A. The damage-response framework of microbial pathogenesis. Nat. Rev. Microbiol. 2003, 1, 17-24. [CrossRef] [PubMed]

103. Naggie, S.; Perfect, J.R. Molds: Hyalohyphomycosis, phaeohyphomycosis, and zygomycosis. Clin. Chest Med. 2009, 30, 337-353, vii-viii. [CrossRef] [PubMed]

104. Kohler, J.; Hube, B.; Puccia, R.; Casadevall, A.; Perfect, J. Fungi that infect humans. Microbiol. Spectr. 2017, 5, 1-29. [CrossRef]

105. Guruprasad, B.; Famna Roohi, N.; Gowda, D. A Review on Candidiasis resistance current drug development process in its prevention and treatment. Int. J. Res. Pharm. Sci. 2020, 11, 1073-1079. [CrossRef]

106. Farjon, A.; Juniperus, L. Flora of Turkey and the East Aegean Islands; Davis, P.H., Cullen, J., Coode, M.J.E., Eds.; Ediburgh University Press: Ediburgh, UK, 2000; Volume 11, pp. 8-10.

107. Shah, P.P.; Mello, P. A review of medicinal uses and pharmacological effects of Mentha piperita. Nat. Prod. Radiance 2004, 3 , 214-221.

108. Nurdjannah, N.; Bermawie, N. Clove. In Handbook of Herbs and Spices; Elsevier: Amsterdam, The Netherlands, $2001 ;$ pp. 154-163.

109. Weedon, D. 25-Mycoses and algal infections. In Weedon's Skin Pathology, 3rd ed.; Weedon, D., Ed.; Churchill Livingstone: Edinburgh, UK, 2010; pp. 581-606.e24.

110. Karpiński, T.M. Essential Oils of Lamiaceae Family Plants as Antifungals. Biomolecules 2020, 10, 103. [CrossRef] [PubMed]

111. Malik, A.; Siddique, M.; Sofi, P.; Butola, J. Ethnomedicinal practices and conservation status of medicinal plants of North Kashmir Himalayas. Res. J. Med. Plant 2011, 5, 515-530.

112. Kumar, K.; Sharma, Y.P.; Manhas, R.; Bhatia, H. Ethnomedicinal plants of Shankaracharya Hill, Srinagar, J\&K, India. J. Ethnopharmacol. 2015, 170, 255-274.

113. Ali, S.; Khan, M.R.; Sajid, M. Protective potential of Parrotiopsis jacquemontiana (Decne) Rehder on carbon tetrachloride induced hepatotoxicity in experimental rats. Biomed. Pharmacother. 2017, 95, 1853-1867. [CrossRef]

114. Bruni, R.; Medici, A.; Andreotti, E.; Fantin, C.; Muzzoli, M.; Dehesa, M.; Romagnoli, C.; Sacchetti, G. Chemical composition and biological activities of Ishpingo essential oil, a traditional Ecuadorian spice from Ocotea quixos (Lam.) Kosterm.(Lauraceae) flower calices. Food Chem. 2004, 85, 415-421. [CrossRef]

115. Fox, L.T.; Mazumder, A.; Dwivedi, A.; Gerber, M.; du Plessis, J.; Hamman, J.H. In vitro wound healing and cytotoxic activity of the gel and whole-leaf materials from selected aloe species. J. Ethnopharmacol. 2017, 200, 1-7. [CrossRef]

116. India, G.O. Ayurvedic Pharmacopoeia of India, Part 11999; Ministry of Health and Family Welfare, Department of Ayush: New Delhi, India, 2011; Volume 1, p. 170.

117. Ishwar, S.; Singh, V. Antifungal properties of aqueous and organic solution extracts of seed plants against Aspergillus flavus and A. niger. Phytomorphology 2000, 50, 151-157.

118. Singh, V.; Ali, M.; Saxena, R.; Shekhar, C.; Anand, D. Volatile constituents and antimicrobial and antifungal activities of immature green seeds of Trachyspermum ammi Linn. J. Essent. Oil Bear. Plants 2008, 11, 120-123. [CrossRef] 
119. Paul, S.; Dubey, R.; Maheswari, D.; Kang, S.C. Trachyspermum ammi (L.) fruit essential oil influencing on membrane permeability and surface characteristics in inhibiting food-borne pathogens. Food Control 2011, 22, 725-731. [CrossRef]

120. Umar, S.; Asif, M.; Sajad, M.; Ansari, M.M.; Hussain, U.; Ahmad, W.; Siddiqui, S.A.; Ahmad, S.; Khan, H.A. Anti-Inflammatory and antioxidant activity of Trachyspermum ammi seeds in collagen induced arthritis in rats. Int. J. Drug Dev. Res. 2012, 4, 210-219.

121. Roy, S.; Chaurvedi, P.; Chowdhary, A. Evaluation of antiviral activity of essential oil of Trachyspermum Ammi against Japanese encephalitis virus. Pharmacogn. Res. 2015, 7, 263-267. [CrossRef] [PubMed]

122. Pozzatti, P.; Scheid, L.A.; Spader, T.B.; Atayde, M.L.; Santurio, J.M.; Alves, S.H. In vitro activity of essential oils extracted from plants used as spices against fluconazole-resistant and fluconazole-susceptible Candida spp. Can. J. Microbiol. 2008, 54, 950-956. [CrossRef] [PubMed]

123. Gatsing, D.; Tchakoute, V.; Ngamga, D.; Kuiate, J.; Tamokou, J.d.D.; Nji-Nkah, B.; Tchouanguep, F.; Fodouop, S. In vitro antibacterial activity of Crinum purpurascens Herb. leaf extract against the Salmonella species causing typhoid fever and its toxicological evaluation. Iran. J. Med. Sci. 2009, 34, 126-136.

124. Akhila, A. Essential Oil-Bearing Grasses: The Genus Cymbopogon; CRC Press: New York, NY, USA, 2009.

125. Hood, J.R.; Wilkinson, J.M.; Cavanagh, H.M.A. Evaluation of Common Antibacterial Screening Methods Utilized in Essential Oil Research. J. Essent. Oil Res. 2003, 15, 428-433. [CrossRef]

126. Ezadi, F.; Ardebili, A.; Mirnejad, R. Antimicrobial Susceptibility Testing for Polymyxins: Challenges, Issues, and Recommendations. J. Clin. Microbiol. 2019, 57, 1-20. [CrossRef] [PubMed]

127. Griffin, S.G.; Markham, J.L.; Leach, D.N. An Agar Dilution Method for the Determination of the Minimum Inhibitory Concentration of Essential Oils. J. Essent. Oil Res. 2000, 12, 249-255. [CrossRef]

128. Chouhan, S.; Sharma, K.; Guleria, S. Antimicrobial Activity of Some Essential Oils-Present Status and Future Perspectives. Medicines 2017, 4, 58. [CrossRef]

129. Chu, Y.; Xu, T.; Gao, C.; Liu, X.; Zhang, N.; Feng, X.; Liu, X.; Shen, X.; Tang, X. Evaluations of physicochemical and biological properties of pullulan-based films incorporated with cinnamon essential oil and Tween 80. Int. J. Biol. Macromol. 2019, 122, 388-394. [CrossRef] [PubMed]

130. Selvamuthukumar, S.; Anandam, S.; Krishnamoorthy, K.; Rajappan, M. Nanosponges: A novel class of drug delivery systemreview. J. Pharm. Pharm. Sci. 2012, 15, 103-111.

131. Minelli, R.; Cavalli, R.; Ellis, L.; Pettazzoni, P.; Trotta, F.; Ciamporcero, E.; Barrera, G.; Fantozzi, R.; Dianzani, C.; Pili, R. Nanosponge-Encapsulated camptothecin exerts anti-tumor activity in human prostate cancer cells. Eur. J. Pharm. Sci. 2012, 47, 686-694. [CrossRef] [PubMed]

132. Prajapati, N.D.; Purohit, S.; Sharma, A.K.; Kumar, T. Handbook of Medicinal Plants: A Complete Source Book; Agrobios Publishers: Jodhpur, India, 2003.

133. Kumar, R.; Srivastava, M.; Dubey, N.K. Evaluation of Cymbopogon martinii oil extract for control of postharvest insect deterioration in cereals and legumes. J. Food Prot. 2007, 70, 172-178. [CrossRef]

134. Gaitanis, G.; Velegraki, A.; Mayser, P.; Bassukas, I.D. Skin diseases associated with Malassezia yeasts: Facts and controversies. Clin. Dermatol. 2013, 31, 455-463. [CrossRef]

135. Velegraki, A.; Cafarchia, C.; Gaitanis, G.; Iatta, R.; Boekhout, T. Malassezia infections in humans and animals: Pathophysiology, detection, and treatment. PLoS Pathog. 2015, 11, e1004523. [CrossRef] [PubMed]

136. Sharma, A.; Rabha, D.; Ahmed, G. In vitro antifungal susceptibility of Malassezia isolates from pityriasis versicolor lesions. Indian J. Dermatol. Venereol. Leprol. 2017, 83, 249-251. [CrossRef]

137. Kordali, S.; Usanmaz, A.; Cakir, A.; Komaki, A.; Ercisli, S. Antifungal and Herbicidal Effects of Fruit Essential Oils of Four Myrtus communis Genotypes. Chem. Biodivers. 2016, 13, 77-84. [CrossRef]

138. Sara, C.; Paola, M.; Melania, R.; Marina, C.; Maurizio, S.; Bruno, M.; Stefania, Z. Antimycotic activity of Myrtus communis L. towards Candida spp. from clinical isolates. J. Infect. Dev. Ctries. 2013, 7. [CrossRef]

139. Deriu, A.; Branca, G.; Molicotti, P.; Pintore, G.; Chessa, M.; Tirillini, B.; Paglietti, B.; Mura, A.; Sechi, L.A.; Fadda, G.; et al. In vitro activity of essential oil of Myrtus communis L. against Helicobacter pylori. Int. J. Antimicrob. Agents 2007, 30, 562-563. [CrossRef]

140. Aleksic, V.; Knezevic, P. Antimicrobial and antioxidative activity of extracts and essential oils of Myrtus communis L. Microbiol. Res. 2014, 169, 240-254. [CrossRef]

141. Jain, S.; Shrivastava, S.; Nayak, S.; Sumbhate, S. PHCOG MAG: Plant review recent trends in Curcuma Longa Linn. Pharmacogn. Rev. 2007, 1, 119-128.

142. Mochizuki, T.; Watanabe, S.; Kawasaki, M.; Tanabe, H.; Ishizaki, H. A Japanese case of tinea corporis caused by Arthroderma benhamiae. J. Dermatol. 2002, 29, 221-225. [CrossRef] [PubMed]

143. Roxburgh, A.C.; Borrie, P. Roxburgh's Common Skin Diseases, 12th ed.; The English Language Book Society and H.K. Lewis and Co. Ltd.: London, UK, 1973.

144. Torres-Alvarez, C.; Castillo, S.; Sánchez-García, E.; Aguilera González, C.; Galindo-Rodríguez, S.A.; Gabaldón-Hernández, J.A.; Báez-González, J.G. Inclusion Complexes of Concentrated Orange Oils and $\beta$-Cyclodextrin: Physicochemical and Biological Characterizations. Molecules 2020, 25, 5109. [CrossRef] [PubMed]

145. Vörös-Horváth, B.; Das, S.; Salem, A.; Nagy, S.; Böszörményi, A.; Kőszegi, T.; Pál, S.; Széchenyi, A. Formulation of Tioconazole and Melaleuca alternifolia Essential Oil Pickering Emulsions for Onychomycosis Topical Treatment. Molecules 2020, $25,5544$. [CrossRef] 